$10-20-2021$

\title{
Frequently asked questions about COVID-19 and family planning/ reproductive health [Arabic]
}

Evidence Project

Follow this and additional works at: https://knowledgecommons.popcouncil.org/departments_sbsr-rh How does access to this work benefit you? Let us know!

\section{Recommended Citation}

Evidence Project. 2021. "Frequently asked questions about COVID-19 and family planning/reproductive health [Arabic]." Cairo: Population Council, The Evidence Project. 


\section{أهمم الأسئلة و الأجوبة المتعلقة بفيروس كورونا و علاقته بالصحة الإلهة الإنجابية وتنظيم الأسرة}

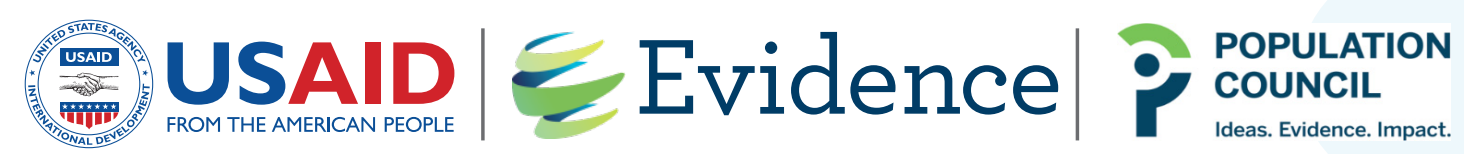





\section{المحتويات}

$\varepsilon$

10

$1 \Lambda$

$\Upsilon \Lambda$

rq
أولاً: الوقاية و التعامـل مـع فيروس كورونا

ثانياً: كوفيد - 19 و تنظيهم الأسرة

ثالثاً: كوفيد - 19 و الحمـل و الولادة و النغاس

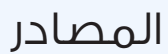

ثكر وتقدير 


$$
\begin{aligned}
& \text { أولاً : الوقاية و التعامـل } \\
& \text { مـع فيروس كورونا }
\end{aligned}
$$

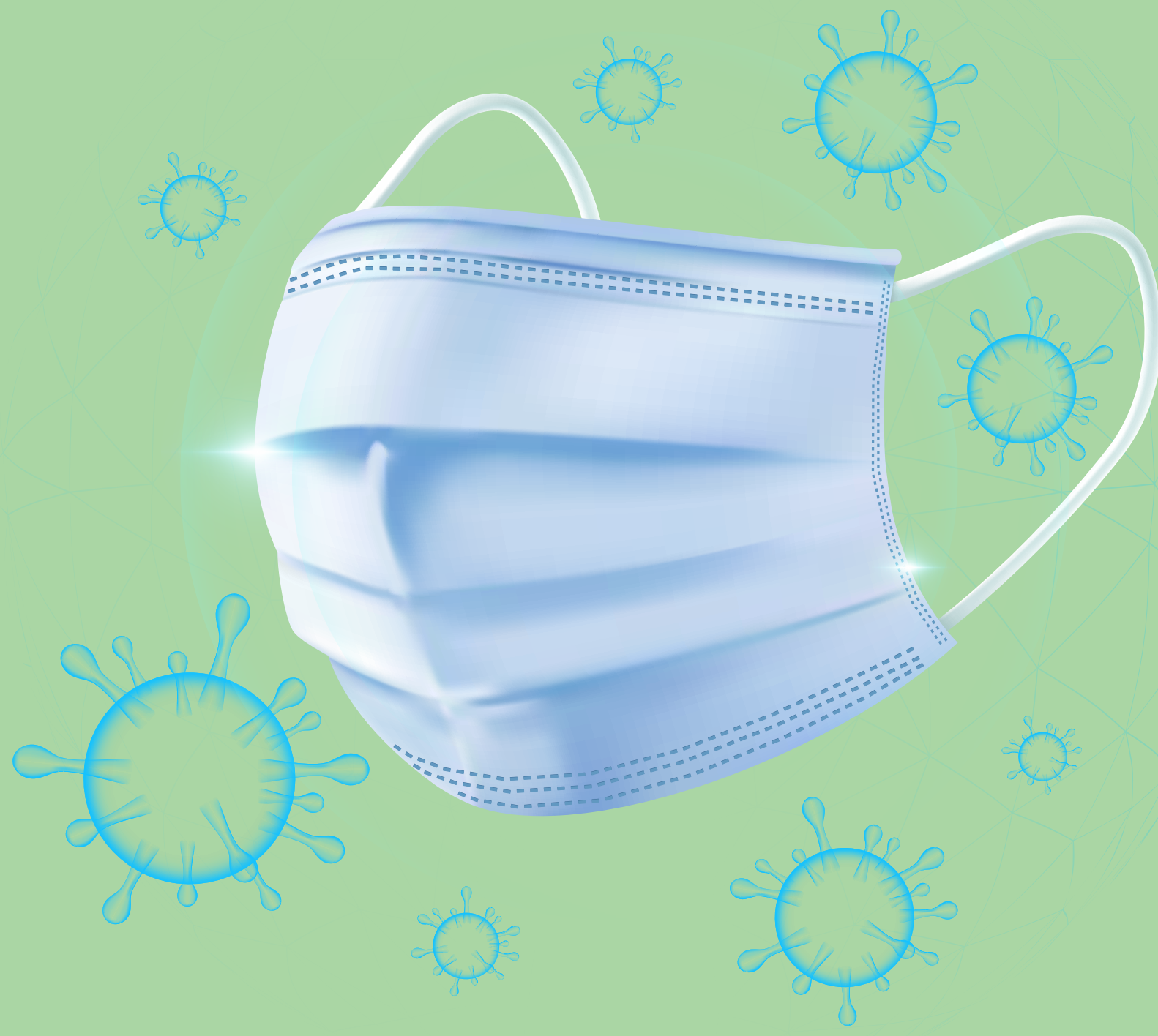




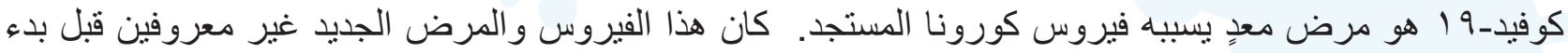

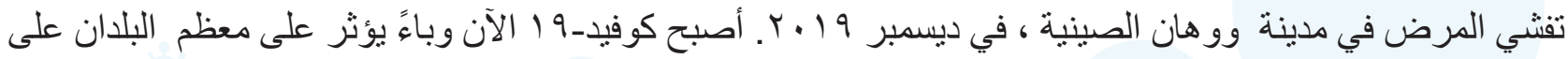

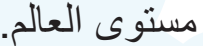

\section{Y- ما هي أعراض مرض كوفيد- 9 (؟}

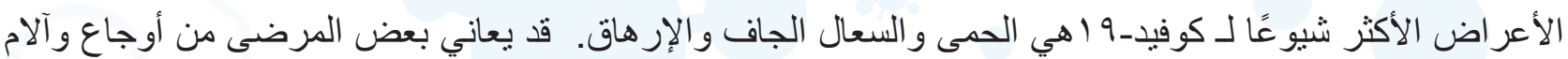

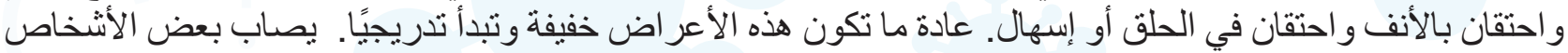

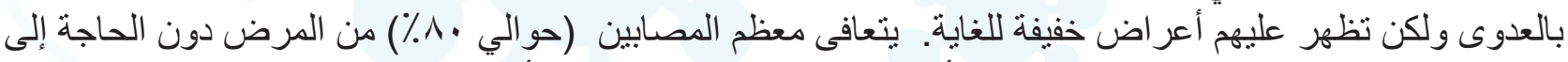

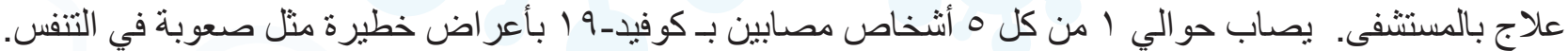

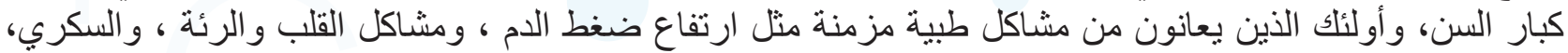

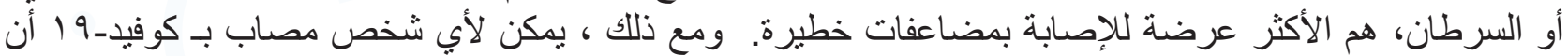
يصاب بأعر اض خطيرة.

حتى الأشخاص الذين يعانون من أعر اض خفيفة جدًا لـ كوفيد-9 1 يمكنهم نقل الفيروس. و ويجب على جميع الأشخاص الذين يعانون من الحمى و السعال وصعوبة التنفس التماس العناية الطبية.

\section{بـ كيف ينتشر مرض كوفيد- 9 (؟}

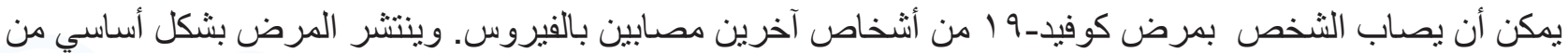

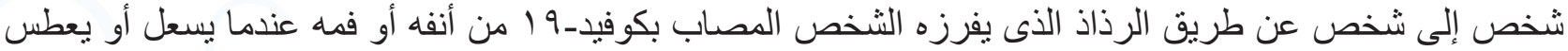

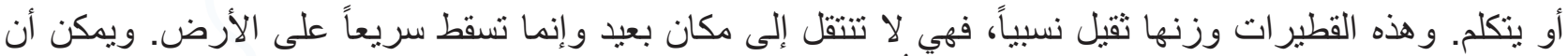
يصاب الثخص بمرض كوفيد-9 1 إذا تتفس هذه القُطير ات من الثخص الثَ المصاب. لذللك من المهم الحفاظ على مسافة متر

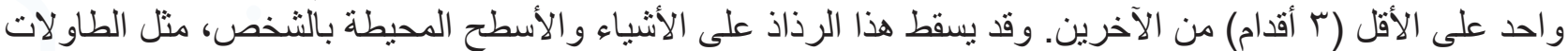

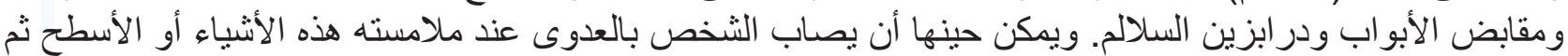

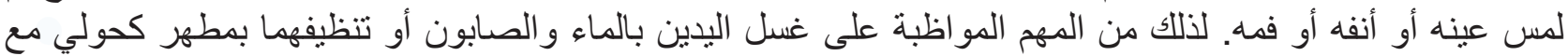
فرك اليدين.

\section{ع- هل يمكن التقاط عدوى كوفيد- 1 من شخص لا تظهر عليه أعراض المرض؟}

تنتشر عدوى كوفيد-19 أساساً عن طريق الرذاذ الذى يفرزه شخص يسعل أو لايه أعر اض أخرى مثل الحمى أو التعب.

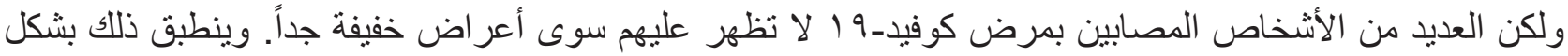

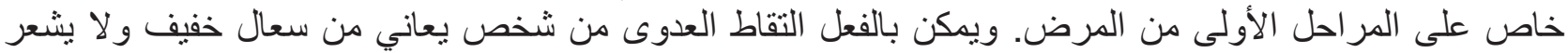
بالمرض.

وتشير بعض التقارير إلى أن الفيروس بمكن أن ينتقل حتى من الأشخاص الذين لا تظهر عليهم أي أعراض. وليس معروفاً حتى الآن مدى انتقال العدوى بهذه الطريقة الطنة

هـ هل يمكن لشخص أن يكون اختباره سلبياً ثم تظهر بعد ذلك نتيجة إيجابية ل كوفيد- 9 1؟

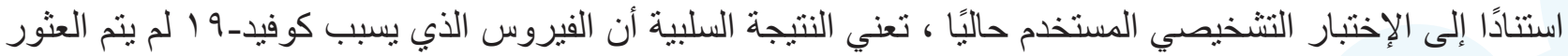
عليه في عينة الثخص. و في المر احل المبكرة من الإصـابة من الممكن ألا يتم اكتثاف الفيروس. لذا يتم إختبار المخالط

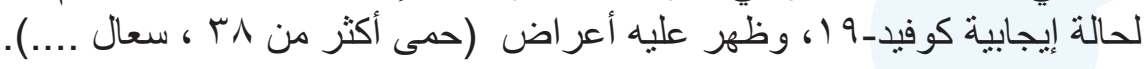
7- ما هو إختبار الأجسام المضادة؟ وهل يمكن إختباري بهذه الطريقة؟

إختبار الأجسام المضادة هو فحص عينة من دم الثخص للبحث عن الأجسام المضادة للفيروس المسبب لـ كوفيد-9 19

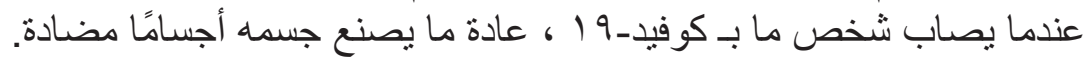




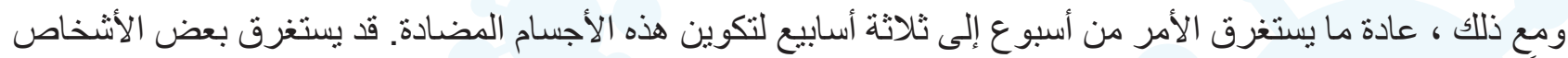

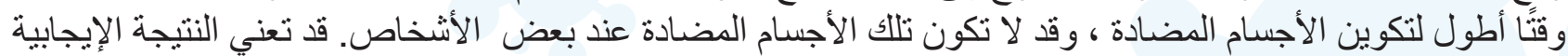

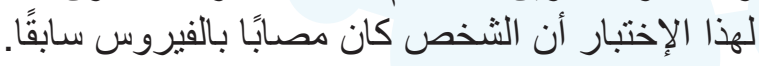

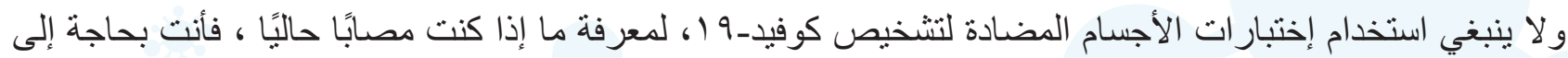
إختبار فيروسى. تحدد الإختبار ات الفيروسية الفيروس في عينات الجهاز التنفسي ، مثل المسحات من داخل الأنف.

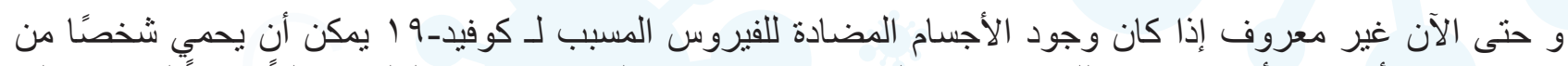
الإصابة مرة أخرى ، أو إذا حدث ذللك ، فكم من الوقت قد تستمر هذه الحماية. يجري العلماء حالياً ابحاثاً للإجابة على الإنى هذه الأسئلة.

\section{V- ما هي مدة بقاء الفيروس على الأسطح?}

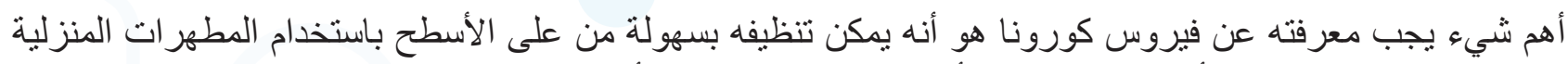

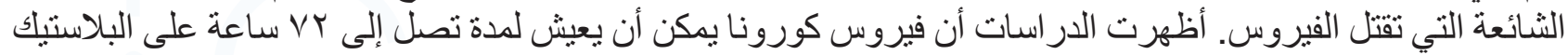

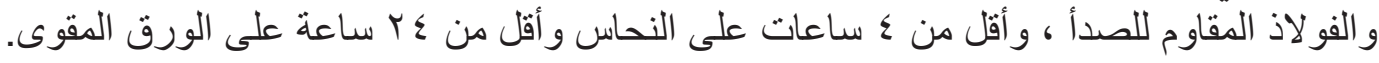
نظف يديك بانتظام بمطهر كحولي لليدين أو اغسلهما بالماء والصابون و تجنب لمس عينيك أو فمك أو أنفك.

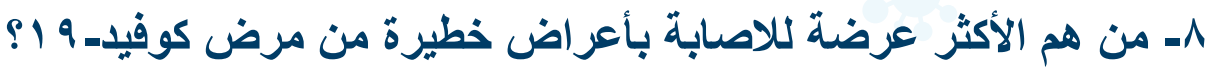

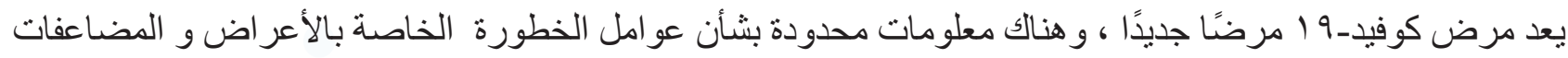

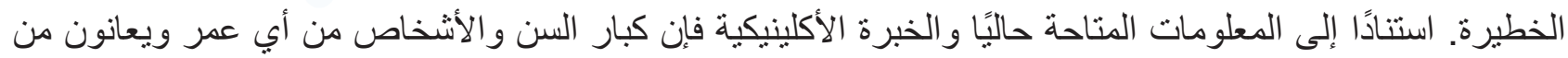

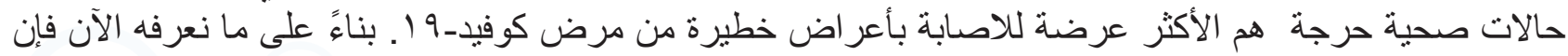

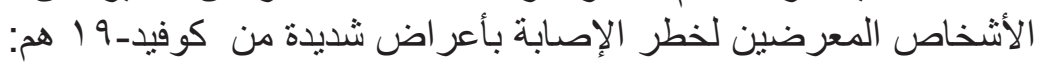

$$
\begin{aligned}
& \text { • الأشخاص الذين تبلغ أعمار هم } 70 \text { عامًا فأكثر. }
\end{aligned}
$$

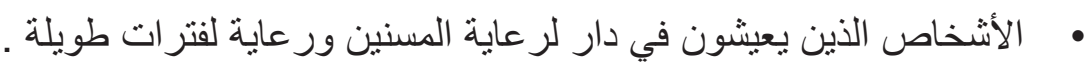

• الأشخاص من جميع الأعمار الذين يعانون من حالات طبية مزمنة ، خاصة إذا لم يتم التحكم فيها جيدًا ، بما في ذلك:

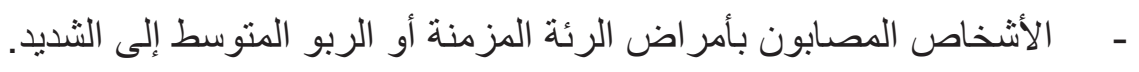

$$
\text { - - الأشخاص الذين يعانون من أمر اض قلبية متقدمة. }
$$

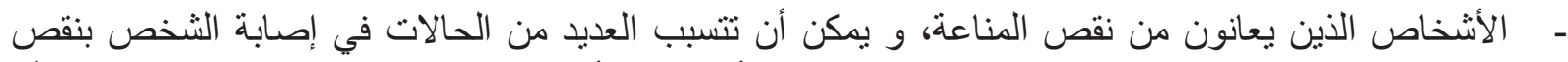

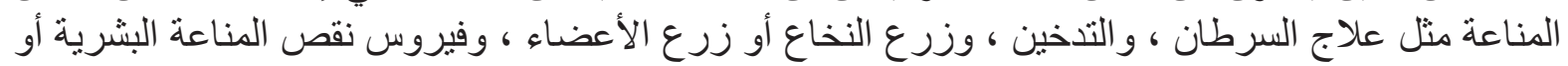

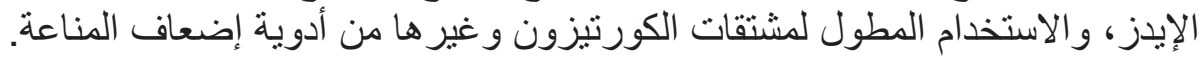

$$
\text { - - مرضى الأشخاص المصابون بالسمنة المفرطة. }
$$

- - الأشخاص المصابون بأمر اض الكلى و يخضعون للغسيل الكلوى.

$$
\text { - }
$$

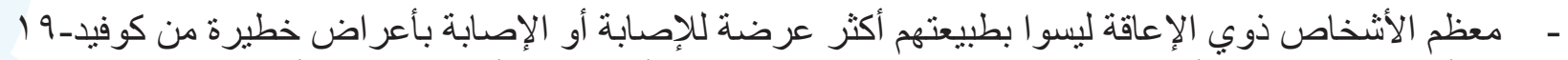

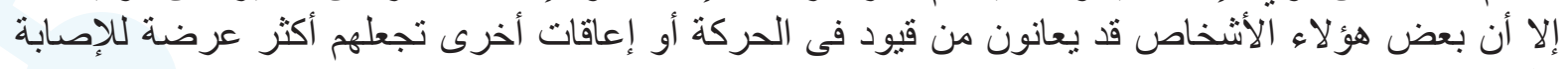

$$
\text { بالعدوى. }
$$

\section{9- هل المدخنون ومستخدمو التبغ أكثر عرضة للإصابة بعدوى كوفيد- 9 (؟}

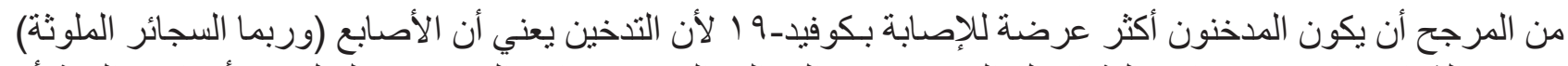

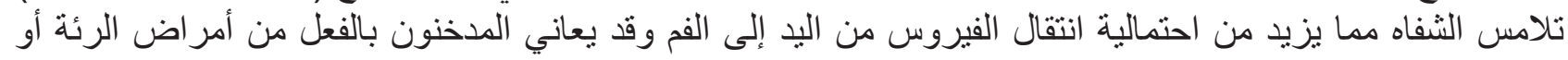




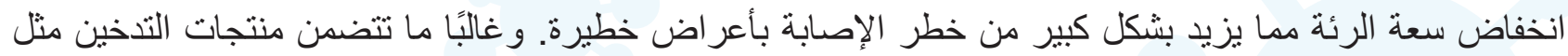

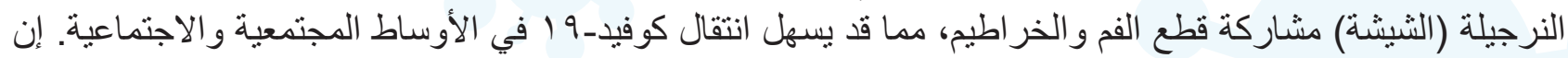
الظروف التي تزيد من احتياجات الأكسجين أو تقلل من قدرة الجسم على استخدامه بشكل صحيح تزيد من خطر الإصـابة الإنية

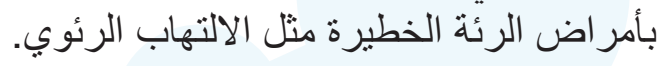

• 1 ـ ما الذي يجب أن يفعله الأشخاص المعرضون لخطر الإصابة باعراض خطيرة من كوفيد-9 1؟ إذا كنت من المعرضين للإصابة باعراض خطيرة من كوفيد-9 1، فيجب عليك: • • اتخاذ الاحتياطات اليومية للحفاظ على مسافة بينك وبين الآخرين.

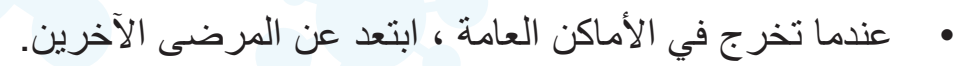

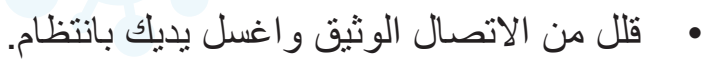

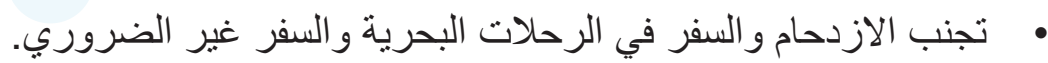
• إذا كان هناك تفتي للمرض في المجتمع المحيط بك ، فابق في المنزل قدر الإمكان و انتبه للأعر اض و علامات الخطرو إذا مرضت ، ابق في في المنزل و اتصل بطبيك.

\section{1 اـ أتناول دواعً لحالة صحية مزمنة، هل يجب علي تغيير أي شيء؟}

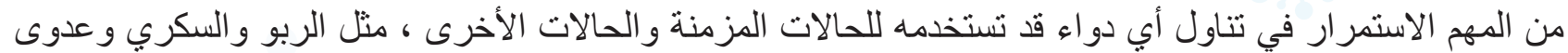

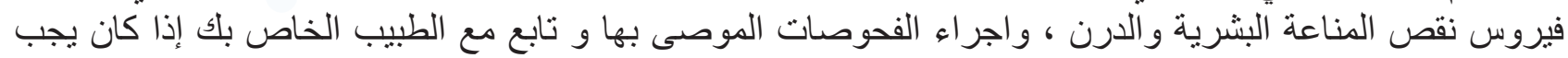

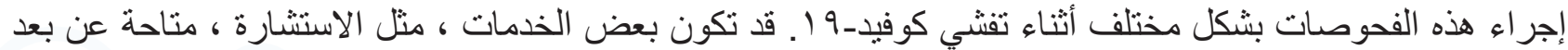

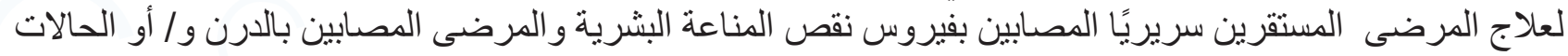

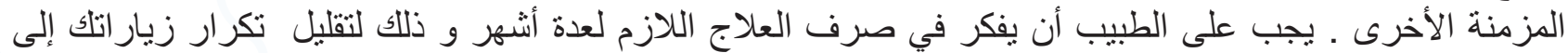

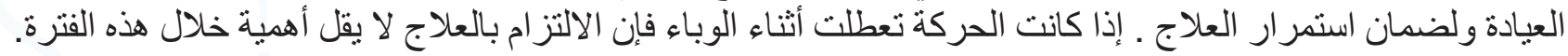

r ا ـ هل ممارسة العلاقة الزوجية آمنة أثناء جائحة كورونا؟ لا يوجد دليل على أن كوفيد-9 1 ينتقل عن طريق السائل المنوي أو السوائل المهبلية.

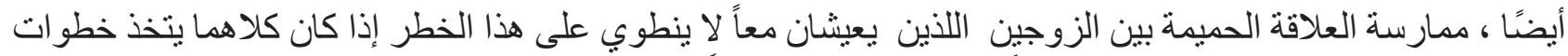

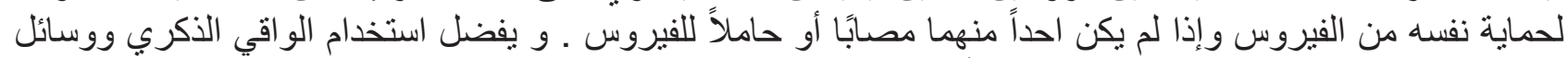

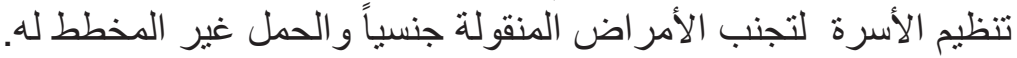

ب ا ـ هل يمكنتي التقاط كوفيد ـ 9 1 من الحيوانات الأليفة؟

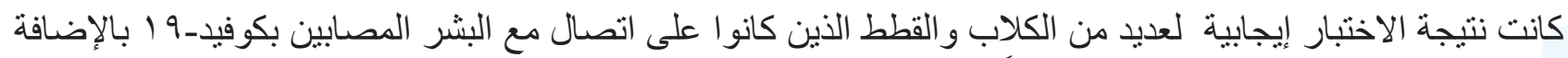

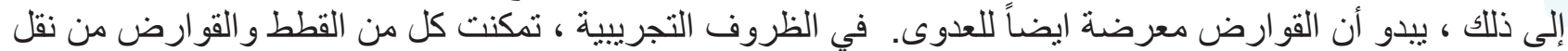

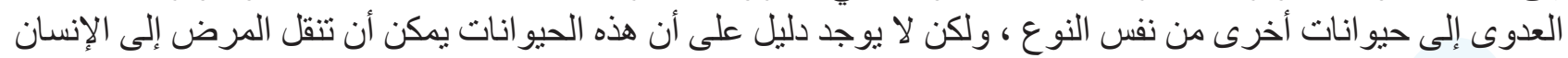

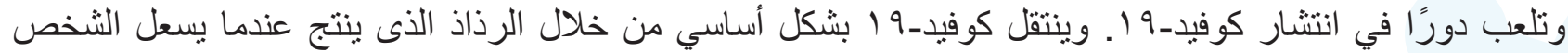

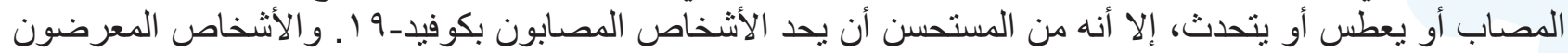

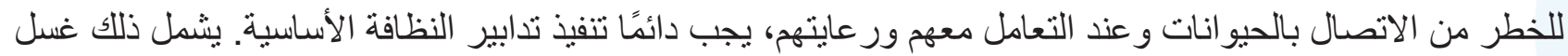
اليدين بعد التعامل مع الحيو انات أو إطعامهم أو لمس الأدوات الخاصة بهم، وكذللك تجنب التقبيل أو لعق أو مشاركة لنّات الطعام.

ع ا- ماذا أفعل لأحمي نفسي وأمنع انتشار المرض؟ كن على علم بأحدث المعلومات حول تفشى كوفيل-9 19، و يمكنك تقليل فرص الإصابة أو نشر المرض من خلال اتخاذ بعض الاحتياطات البسيطة: 


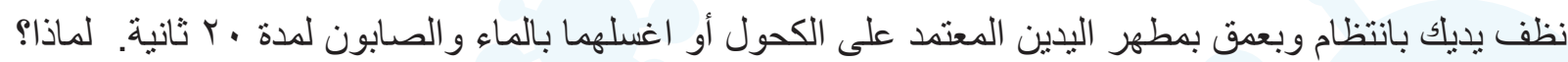

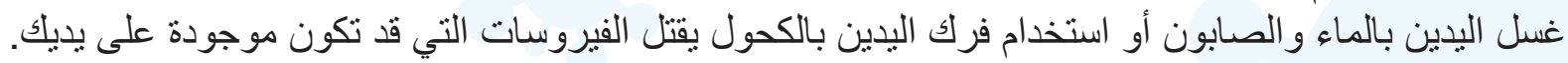

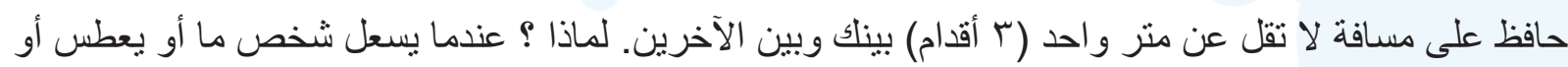

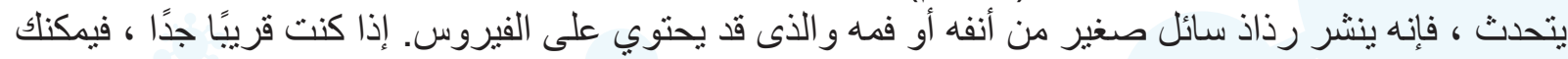

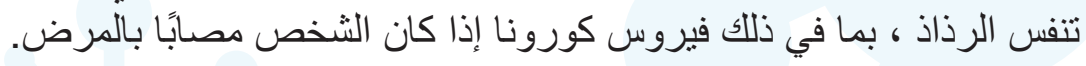

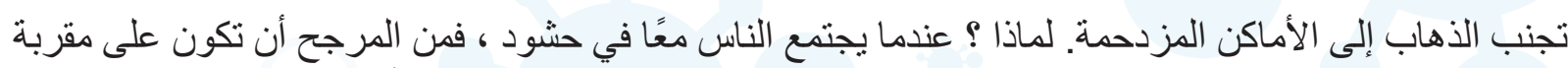

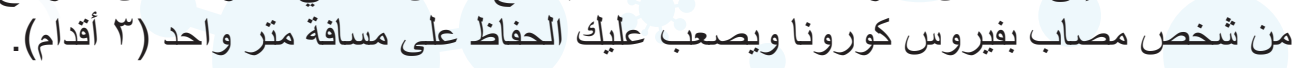
تجنب لمس العينين و الأنف و الفم. لماذا ؟ تلمس الأبدي العديد من الأسطح ويمكنها التقاط الفيروسات. بمجرد التلوث،

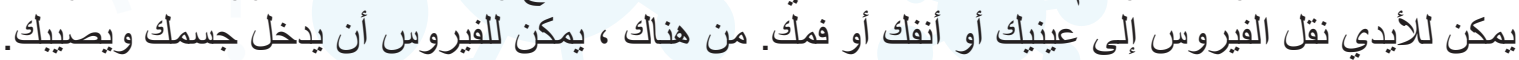
تأكد من إتباعلك أنت ومن حوللك لنظافة الجهاز التنفسي جيداً. و هذا يعني تغطية فمك و وأنفك بكو علك المثني أو بمنديل

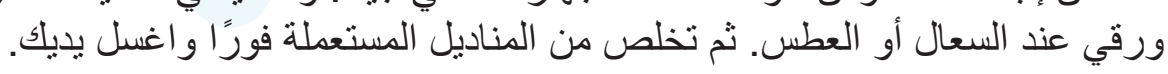

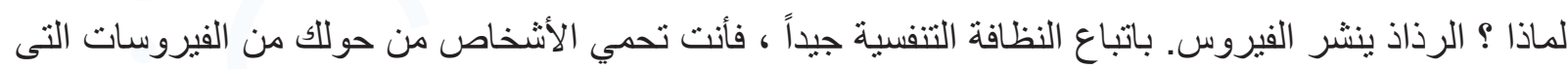
تسبب البرد و الإنفلونز او كوفيد- 19 ابق في المنزل واعزل نفسك حتى مع ظهور أعر اض طفيفة مثل السعال والصداع والحمدى الحنى الخفيفة إلى أن تتعافى.

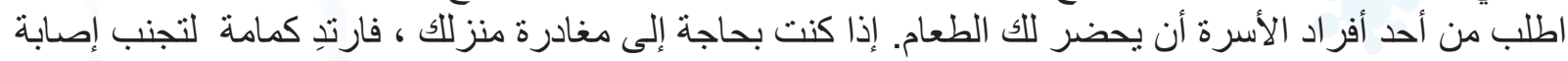

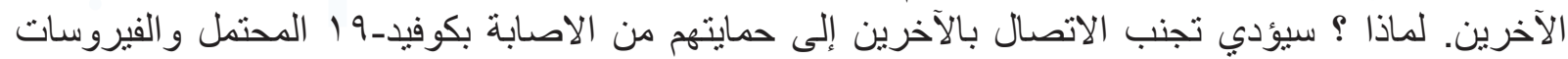
الأخرى.

إذا كنت تعاني من الحمى و السعال وصعوبة التنفس ، فاطلب العناية الطبية ، ولكن اتصل بمقدم الخدمة عن طريق الهاتف مسبقًا إن أمكن. ابق على اطلاع بأحدث المعلومات من مصادر موثوقة، مثل منظمة الصحة العالمية و وزارة الصنات الصحة و والسكان.

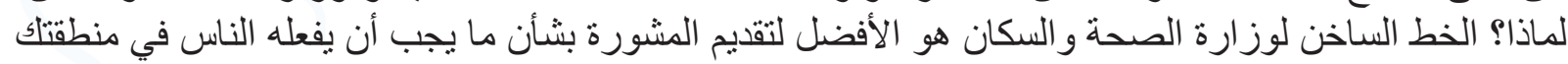
لحماية أنفسهم. لماذو الخطاخ

\section{1 ـ ماذا يعني العزل المنزلي؟}

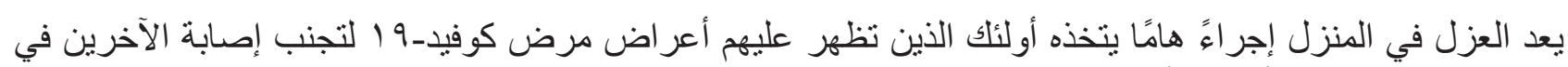
المجتمع ، بماً في ذللك أفر اد الأسرة.

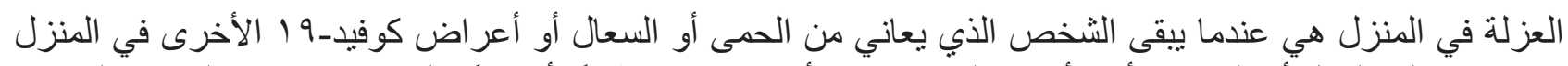

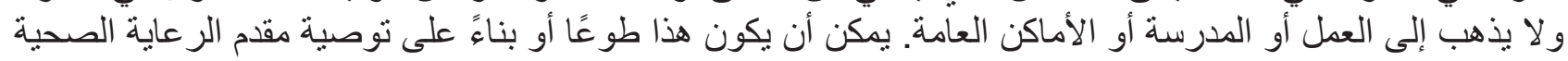

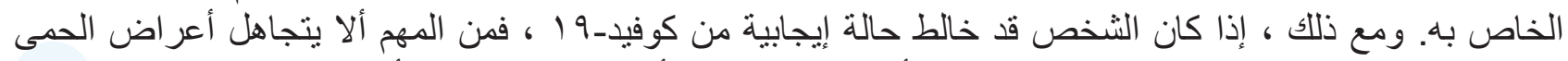

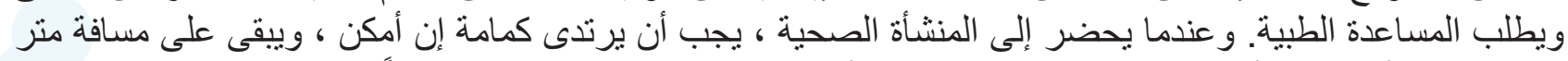

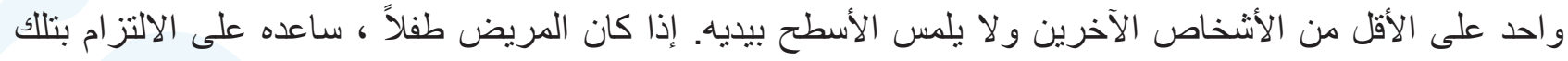
النصائح.

إذا كان الشخص في عزل منزلى بسبب مرضه دون أن يكون لايه اعراض شديدة تتطلب عناية طبية للعزل الذاتي،

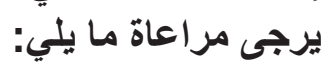

- وجود مساحة كبيرة جيدة التهوية مع مر اعاة نظافة اليدين ودور ات المياه.

- - - إذا لم يكن ذلك ممكنًا ، فضع الأسرّة على مسافة منر و واحد على الأقل. - ابق على بعد متر واحد (ץ أقدام) على الأقل من الآخرين ، حتى من أفر اد عائلتك.

$$
\text { - مر - مراقبة الأعر اض اليومية. }
$$

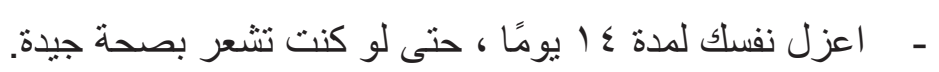


- إذا كنت تعاني من صعوبة في التنفس ، اتصل بمقدم الرعاية الصحية الخاص بك على الفور - اتصل به أولاً إذا

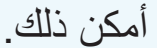
- ـ كن إيجابيًا ونشطًا من خلال البقاء على اتصال مع أحبائك عبر الهاتف أو عبر الإنترنت ، ومن خلال ممارسة

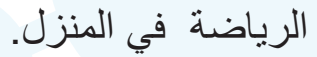

7 ا ـ ماذا أفعل إذا كاتت لابي أعراض كوفيد-9 1 ومتى يجب علي طلب الرعاية الطبية؟

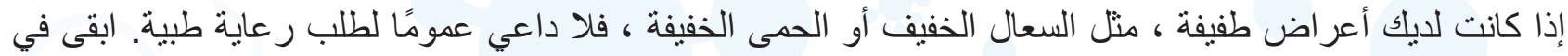

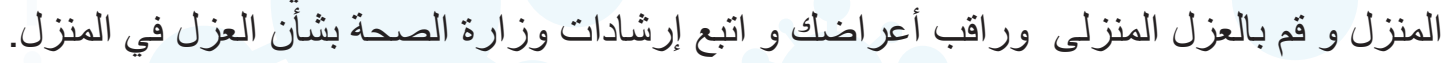
ومع ذللك ، إذا كنت قد خالطت حالة إيجابية لكوفيد-9 (، فمن المهم ألا تتجاهل أعر اض الحمى و اطلب المساعدة الطبية.

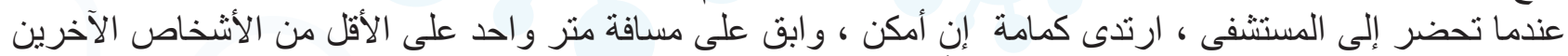

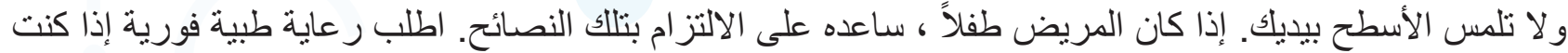

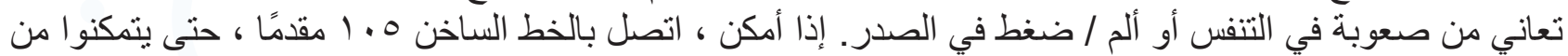
توجيهك إلى المرفق الصحي المناسب.

\section{I ا - ماذا أفعل إذا أصيب شخص ما في منزلي بفيروس كورونـا؟} سيتمكن معظم الأشخاص الذين يصابون بـ كوفيد-9 ألمن التعافي في المنزل. و تقدم وزارة الصحة و السكان إرشادات

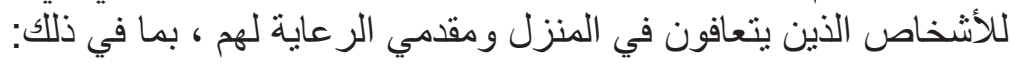
• ابق في المنزل عندما تكون مريضًا ، باستنتاء الحصول على الرعاية الطبية. • استخدم غرفة وحمام منفصلين لأفر اد الأسرة المرضى (إن أمكن).

• اغسل يديك كثيرًا بالماء و الصابون لمدة • ب ثانية على الأقل ، خاصة بعد نفت الأنف أو السعال أو العطس او بعد

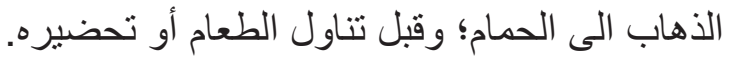

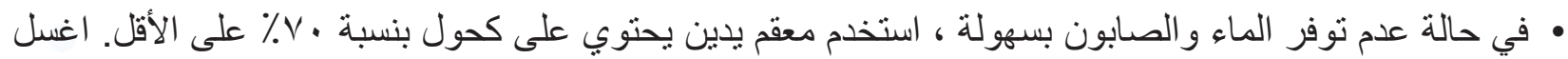

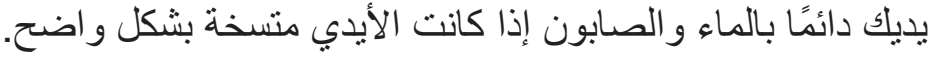
• زود فرد أسرتلك المريض بكمامة وجه نظيفة يمكن التخلص منها لارتدائها في المنزل ، إذا كان ذلك متاحًا ،

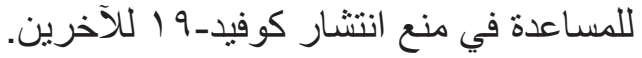
• نظف غرفة المرضى و الحمام ، حسب الحاجة ، لتجنب الاتصال غير الضروري مع المريض. • تجنب مشاركة الأغر اض الثخصية منل الأواني و الطعام و المشروبات مع الثخص المريض.

متى تطلب العناية الطبية:

إذا ظهرت عليك أعر اض خطيرة لكوفيد-19 ، احصل على رعاية طبية على الفور. الأعر اض الخطيرة تشمل:

$$
\begin{aligned}
& \text { - } \\
& \text { - - ألم أو ضغط مستمر في الصدر. }
\end{aligned}
$$

قلة التركيزو الأرتباك أو عدم القدرة على الاستجابة.

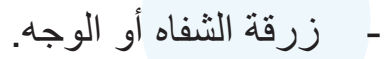

1 ا ـهل يوجد لقاح او دواء او علاج لقيروس كورونا؟

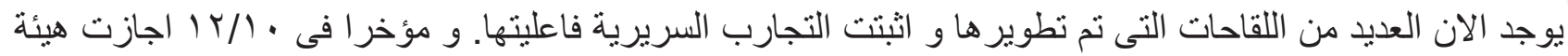

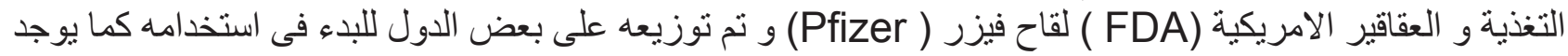
انو اع اخرى سوف تطرح مثل : 


\section{AstraZeneca's COVID-19 vaccine Janssen's COVID-19 vaccine Moderna's COVID-19 vaccine Novavax's COVID-19 vaccine}

و نجحت وز ارة الصحة و السكان بمصر فى الحصول على جر عات من لقاح تم تطويره بو اسطة شركة سينوفارم الصينية و كذلك تم التعاقد على انواع اضافية من اللقاحات مثل استر ازنيكاو يتم حالياً تطعيم الاطقم الطبية و كبار السن و اصحاب الامر اض المزمنة على أن يتم تطعيم باقى شر أئج المجتمع تباعاً.

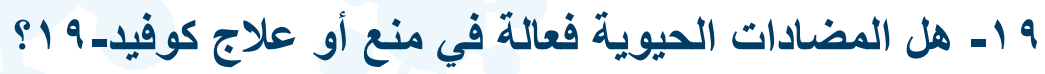
لا. المضادات الحيوية لا تعمل ضد الفيروسات. هم يعملون فقط على الالتهابات البكتيرية. يحدث مرض كوفيد-19

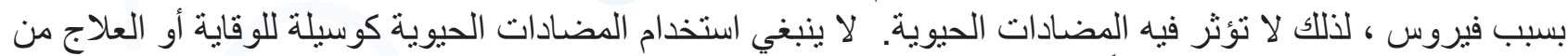

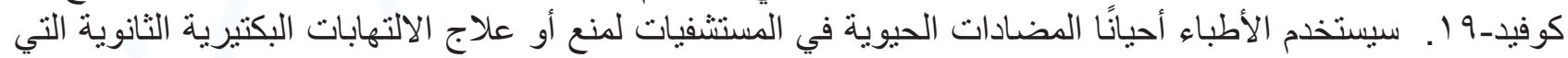

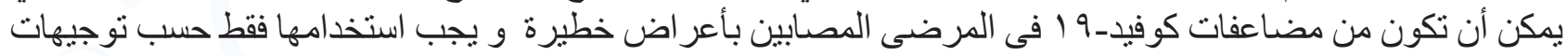
الطبيب لعلاج العدوى البكنيرية.

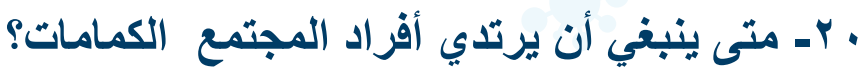

ينبخي أن يرتدي أفر اد المجتمع كمامات في الأماكن التي يتعذّر فيها الحفاظ على مسافة لا تقل عن متر واحد من من الآخرين.

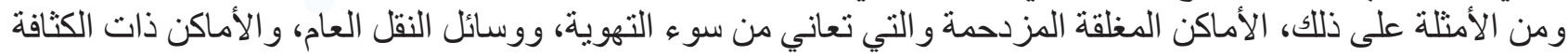

السكانية العالية، و غير ها.

وفي الأماكن المغلقة، ولا سيما تلك التي تعاني من سوء التهوية، من المهم جدًا زيادة معدل تجديد الهو اء، و الحد من إعادة تلدوير الهو اء، وزيادة استخدام الهو اءعة الخارجي.

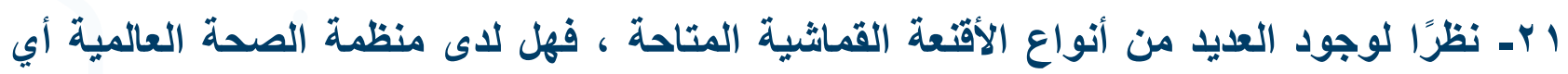

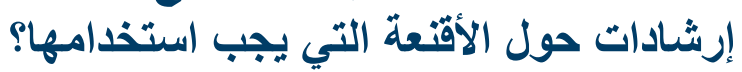

تقوم منظمة الصحة العالمية بدر اسات بشأن مواصفات الأقعدة. حددت نتائج البحوث الأنو اع التالية المفضلة من الأقششة، و عدد الطبقات وتكوين القناع القماش الغير طبي:

• طبقة داخلية من مادة ماصة مثل القطن. • • طبقة وسطى من مادة مثل البولي بروبلين.

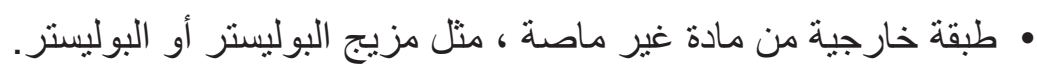

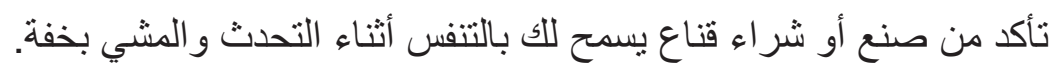

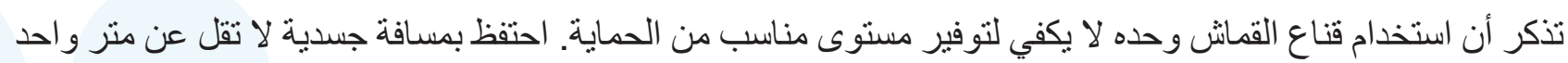
عن الآخرين ونظف يديك بشكل متكرر.

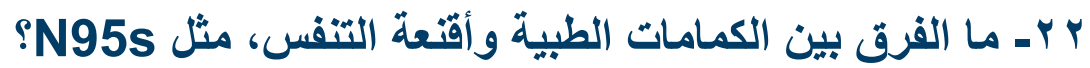
الكمامات الطبية (المعروفة أيضاً باسم الكمامات الجراحية)، التكوين: • مصنو عة من ثلاث طبقات من المواد غير المنسوجة الاصطناعية. • مركبة على نحو يحصر طبقات الترشيح في المنتصف. • متوفرة بدرجات سمك مختلفة. • تنظوي على مستويات مختلفة من مقاومة السو ائل و الترشيح. 
أقنعة التنفس (المعروفة أيضا باسم أقنعة الوجه التنفّسية المرشّحة ( FFP) و (FFP) المتاحة بمستويات متفاوتة الأداء، مثل N99 و $\mathrm{N} 95$, FFP2

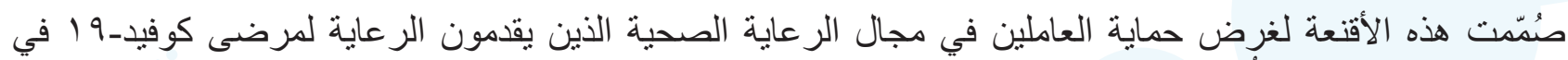

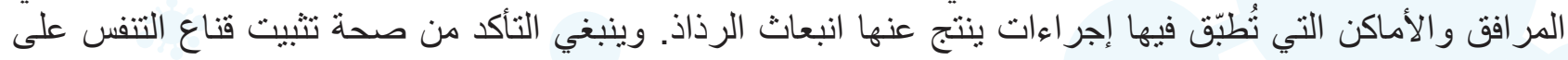

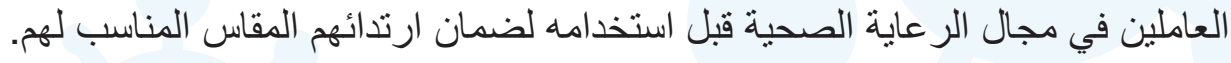

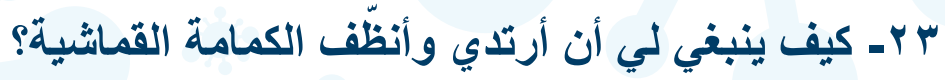
كيفية ارتداء وحمل الكمامة القماشية: • قبل لمس الكمامة، نظف يديك بفركها بمطهر كحولي أو بغسلهما بالماء والصابون.

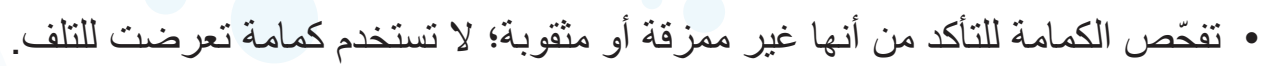
• اضبط الكمامة بحيث تغطي أنفك وفمك وذقنك، واحرص على على عدم ترك أي فر اغات على الجانبين. ثتبت شريطيْ الكمامة خلف الر أس أو الأذنين.

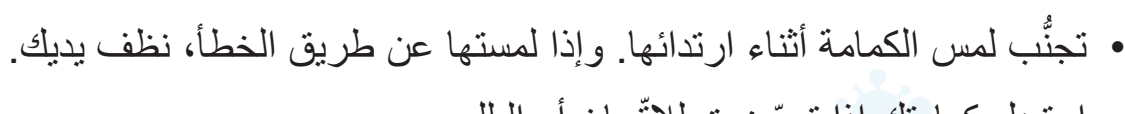
• • استبدل كمامتلك إذا تعرّضت للاثّساخ أو البلل.

كيفية خلع وحفظ الكمامة القماشية:

• نظّف يديك قبل خلع الكمامة. • اخلع الكمامة بنزع شريطيْ الأذن، دون لمس الجهة الأمامية من الكمامة.

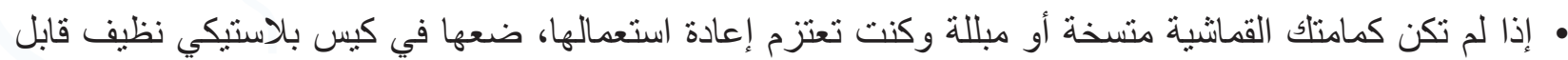

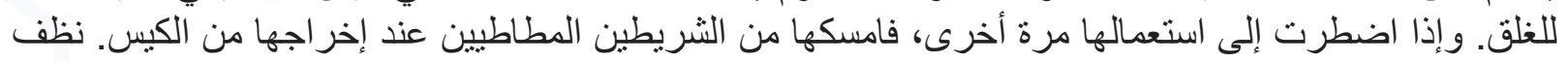

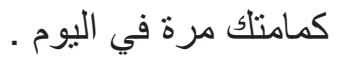
• • نظّف يديك قبل خلع الكمامة. كيفية تنظيف الكمامة القماشية:

• اغسل الكمامات القماثنية بالصابون أو المنظِّف، ويُفضل استخدام الماء الساخن (لا تقل حرارته عن ـ بـ درجة مئوية) مرة في اليوم على الأقل. • إذا تعذّر غسل الكمامة بالماء الساخن، يمكنك القيام بما ليلي:

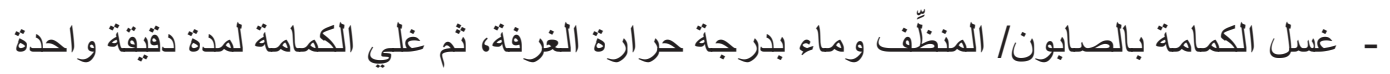
ـ ـ أونقع الكمامة في محلول الكلور بتركيز , ، • لمدة دقيقة واحدة ثم غسلها جيداً بالماء بدرجة حرارة الغرفة (ينبغي ألا يتبقى أي أثر سام للكلور على الكمامة). • تأكد من أن لديك كمامتلك الخاصة ولا تشاركها مع الآخرين. تذكر أن استخدام الكمامة القماش وحدها لا يكفي لتوفير مستوى مناسب من الحماية. احتفظ بمسافة جسدية لا تقل عن منر واحد عن الآخرين ونظف يديك بشكل متكرر.

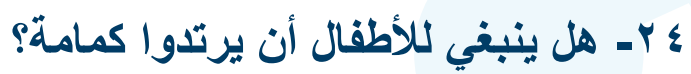

لا ينبغي إلز ام الأطفال البالغين من العمر ه سنو ات أو أقل بارتداء كمامة. وتقدم هذه النصيحة لسلامة الطفل ومصلحته

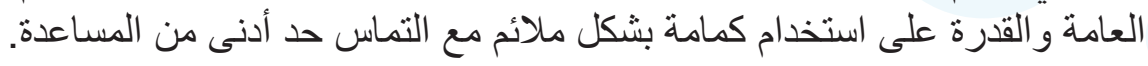

وتتصح منظمة الصحة العالمية واليونيسيف بأن يستند قرار ارتداء الأطفال الذين تتراوح أعمار هم من 7 سنوات إلى 11 إلى سنة للكمامات إلى العو امل التالية: 
• ما إذا كان هناك انتقال واسع النطاق للعدوى في المنطقة التي يقيم فيها الطفل. • قدرة الطفل على استخدام الكمامة بشكل مأمون وملائم.

• فرص الحصول على الكمامات، فضلا عن إمكانية غسلها واستبدالها في بعض الأماكن المعينة (مثل المدارس ومر افق رعاية الأطفال).

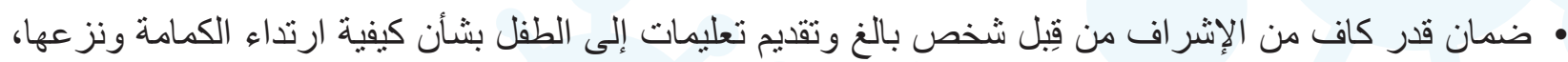
واستخدامها بأمان.

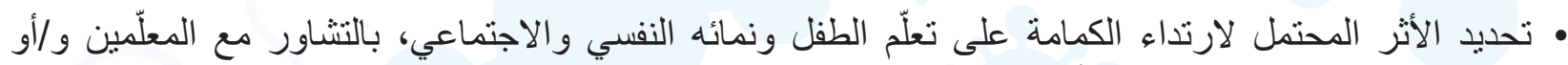

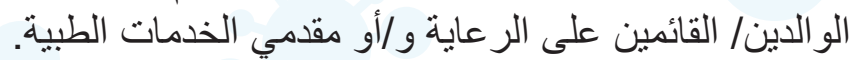

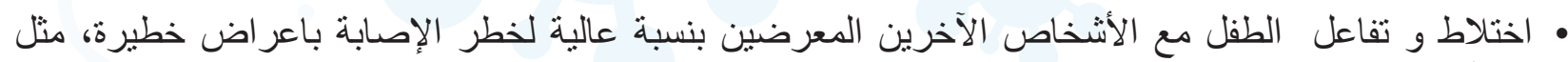

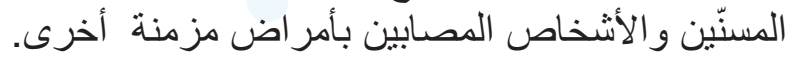

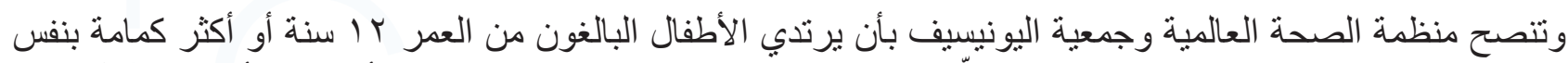

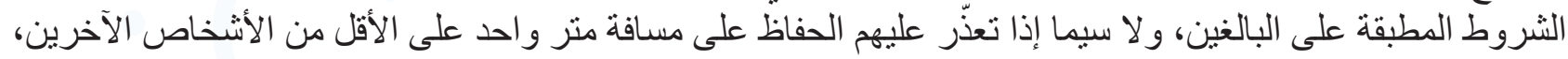
و إذا كان هنالك انتقال واسع النطاق للعدوى في المنطقة.

ه - هل هل توصي منظمة الصحة العالمية باستخدام القفازات في أوساط المجتمع المحلي للوقاية من

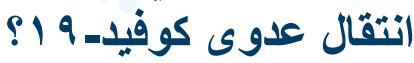

كلا. لا توصي المنظمة بتعميم استعمال القفاز ات بين أفراد المجتمع المحلي. وبدلاً من ذلك، توصي بتركيب محطات/

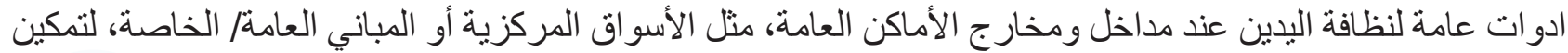

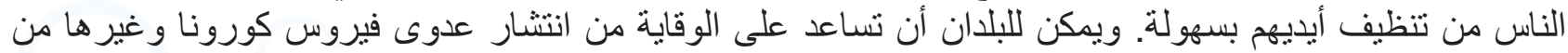

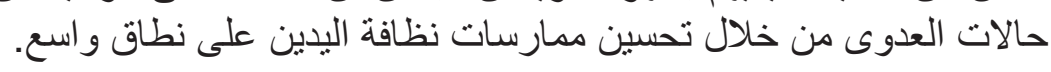

\section{צ Y ـ كيف يمكني حماية طقلي من الإصابة بعدوى كوفيد- 9 1؟}

يمكنك تشجيع طفلك على المساعدة في وقف انتشار كوفيد-9 1 من خلال تعليمه القيام بنفس الأشياء التي يجب على الجميع القيام بها للبقاء بصحة جيدة.

• تجنب الاتصال الوثيق مع الناس الذين يعانون من المرض.

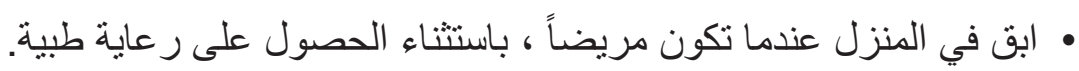

• غطٌّ الأنف و الفم أثناء السعال أو العطس بمنديل ورميه في سلة المهملات.

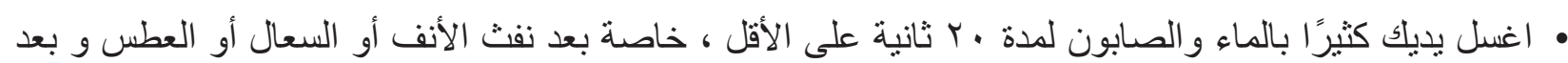

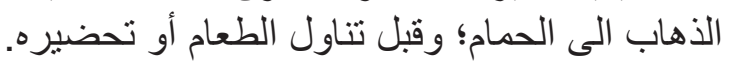

• في حالة عدم توفر الماء و الصابون ، استخدم معقم يدين بحتوي على كحول بنسبة • ×٪ على الأقل. اغسل يديك دائمًا بالَماء و الصابون إذا كانت الأيدي منسخة بشكل و واضح.

• قم بتنظيف وتطهير الأسطح والأشياء التي يتم لمسها بشكل متكرر (مثل الطاولات وأسطح العمل ومفاتيح الإضاءة ومقابض الأبو اب ومقابض الخز الانات).

• اغسل الأشياء ، بما في ذلك الألعاب القماثية القابلة للغسل ، إذا أمكن. اغسل الالعاب باستخدام الماء الساخن ثم جفقها

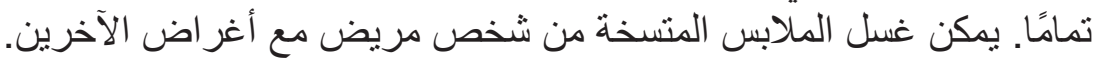

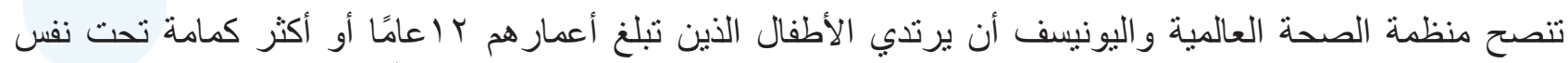

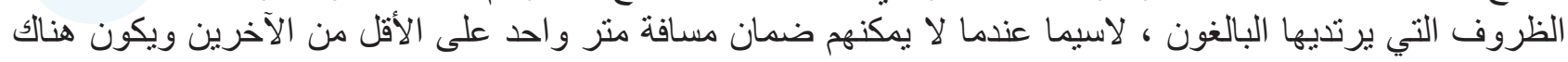
انتقال واسع النطاق في المنطقة. 


\section{V - ما هي تدابير الوقاية والمكافحة التي ينبغي إعدادها واتخاذها في المدارس؟}

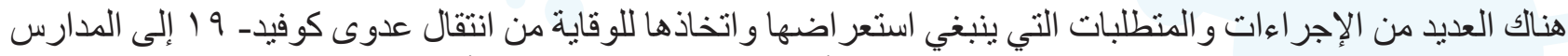

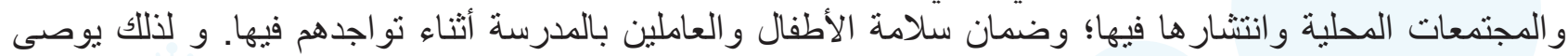

التدابير المتخذة على مستوى المجتمع المحلي: الكثف المبكر عن المخالطين واختبار هم وتتبّعهم ووضعهم في الحجر

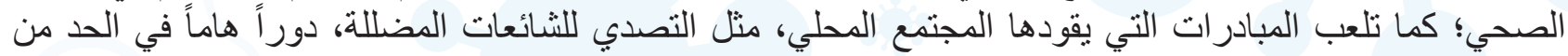
مخاطر العدوى.

السياسات والممارسات والبنية التحتية: ضمان تو افر الموارد و السياسات والبنية التحتية اللازمة لحماية صحة وسلامة

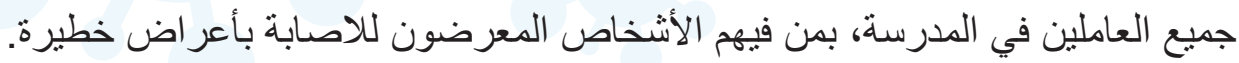

الجواتب السلوكية: مر اعاة عمر الطلاب وقدرتهم على فهم واحترام التدابير المتخذة. وقد يجد الأطفال الصغارصعوبة

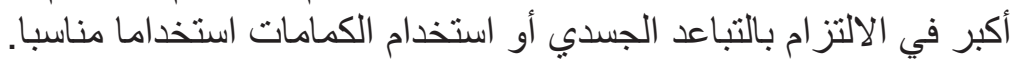

السلامة والأمن: قد يؤثر إغلاق المدارس أو إعادة فتحها على سلامة الطلاب وأمنهم، وقد يحتاج الأطفال الأكثر ضعفاً

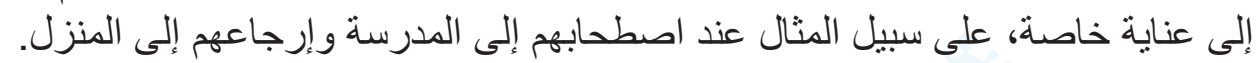

النظافة العامة والممارسات اليومية على مستوى المدرسة والأقسام: للحد من التعرّض للعدوى، ينبغي الحفاظ على التى

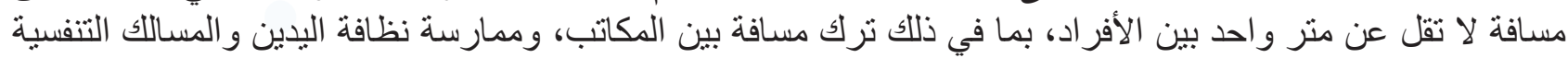

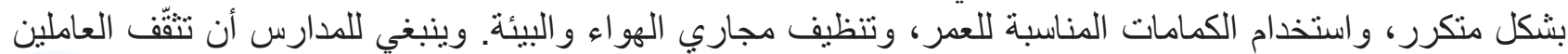

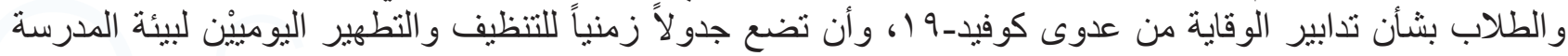

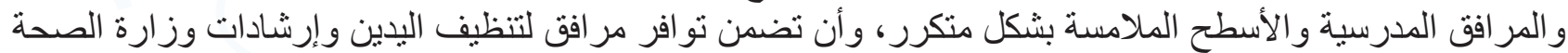
و السكان بشأن استخدام الكمامات.

فحص المرضى من الطلاب والمعلمين وغيرهم من موظفي المدرسة وتقايم الرعاية لهم: ينبغي للمدارس أن تطبق

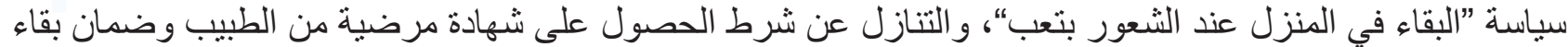

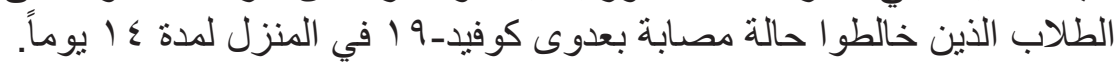

حماية الاشخاص المعرضين لأعراض خطيرة: ينبغي للمدارس أن تحدد الطلاب والمعلمين المعرضين لأعر اض خطيرة

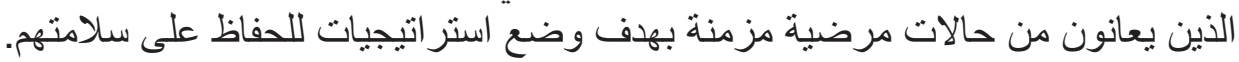

التواصل مع الوالدين والطلاب: ينبغي للمدارس أن تطلع الطلاب و الوالدين باستمر ار على التدابير الجاري تنفيذها لضمان تعاونهم ودعمهم.

تدابير إضافية متعلقة بالمدرسة: لضمان استمر ارية الخدمات الأساسية أو توسيعها، بما في ذلك التغذية المدرسية والصحة النفسية و الدعم النفسي والاجتماعي. متعة بالمدرية

التباعد الأجتماعى خارج الفصول: الحفاظ على مسافة لا تقل عن متر واحد بين الطلاب (جميع الفئات العمرية) وبين العاملين، قدر الإمكان.

التباعد الجسدي داخل الفصول : ينبخي الحفاظ على مسافة لا تقل عن متر و احد بين جميع الأفر اد من جميع الفئات العمرية

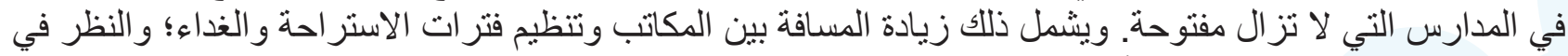
خف عدد التلاميذ في كل فصل أو وضع جداول لحضور الدروس بالتناوب، وضمان تهوية جيدة في الفصول.

التعلم عن بعد: حيثما يتعذّر على الأطفال حضور الدروس شخصياً، ينبغي تقديم الدعم لضمان استمرار الطلاب في

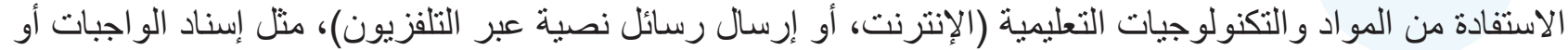
بث الدروس عبر تللك الوسائط. و لا ينبغي النظر في إغلاق المر افق التعليمية إلا في حال عدم توفر بدائل الذان لذلك. 
^ץ - ما هي منتجات التنظيف والتعقيم التي يجب أن أستخدمها للحماية من كوفيد-9 1؟

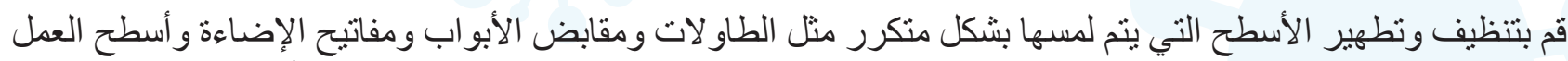

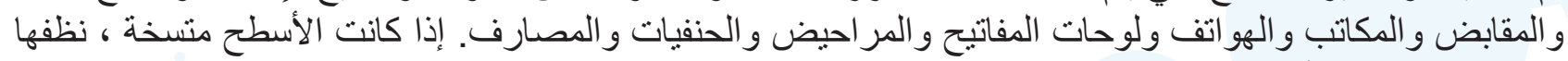
باستخدام المنظفات أو الصابون و الماء قبل التعقيم. للتطهير ، استعمل معظم المطهر ات المنزلية الثائعة. و يحضرمحلول الكلور عن طريق خلط: ع ملاعق صغيرة من 0\% كلورلكل لتر ماء بدرجة حرارة الغرفة، أو كوب كلور تركيز ه\% على 0 لتر ماء. ستكون محاليل الكلورفعالة للتطهير لمدة تصل إلى ؟r ساعة. يمكن أيضًا استخدام محاليل الكحول التي تحتوي على • ٪\% كحول على الأقل.

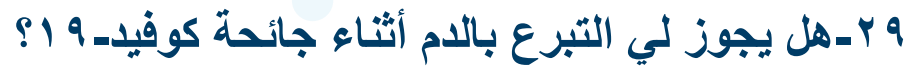

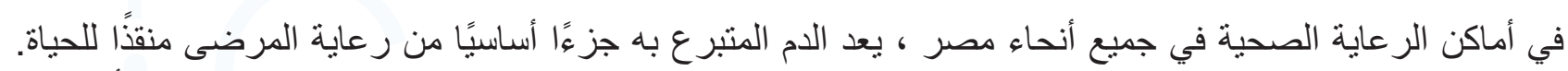

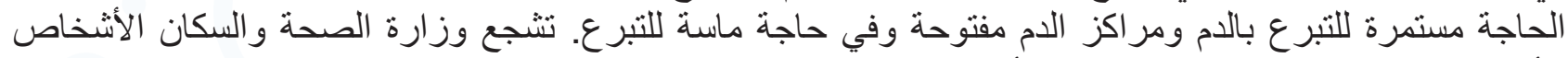

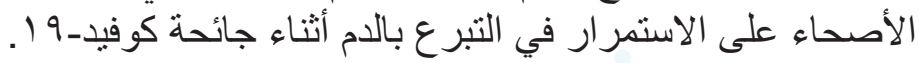




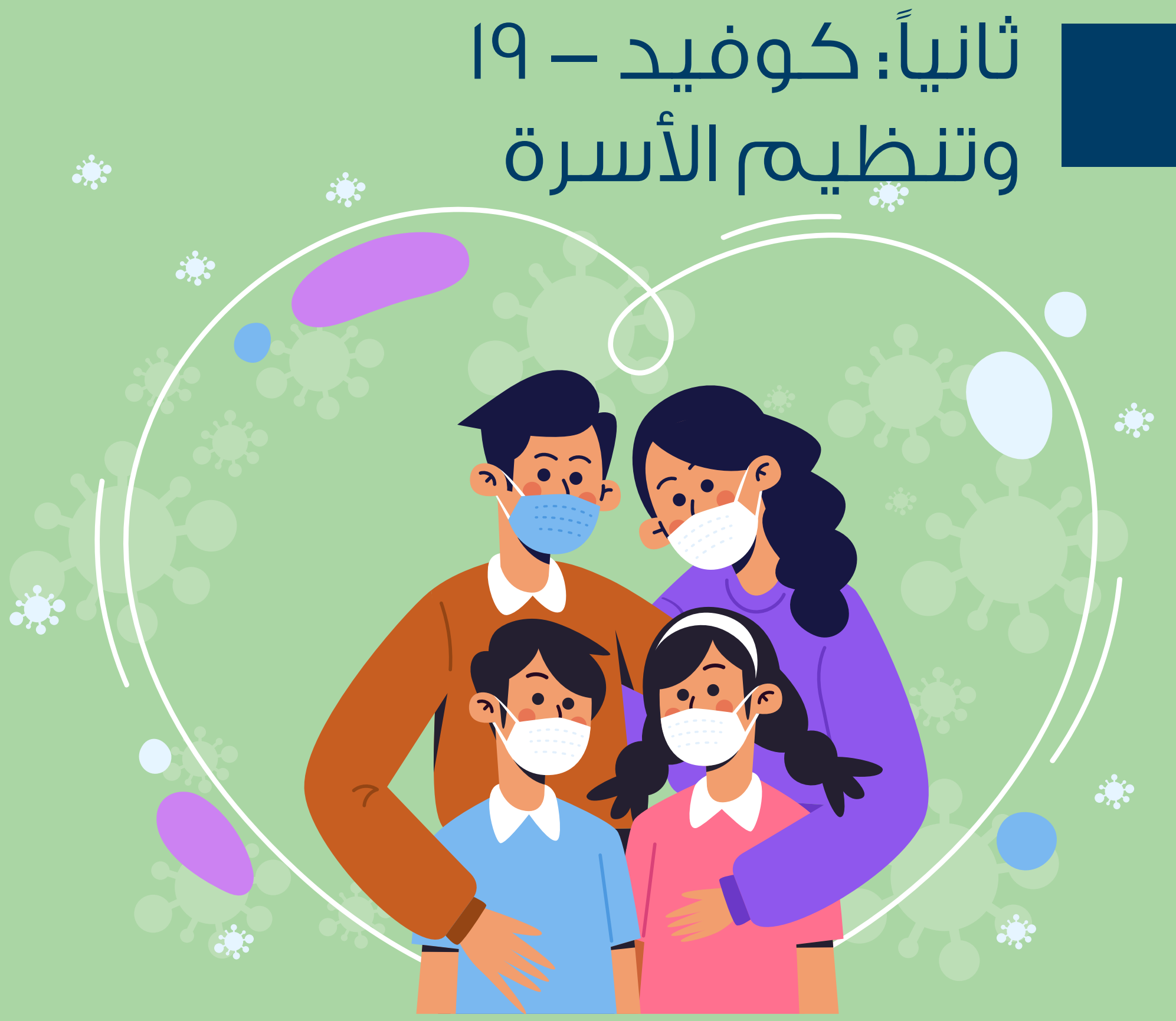


نعم. جميع وسائل تنظيم الأسرة الحديثة آمنة للاستخدام، بما في ذلك أثناء جائحة كوفيد-9 1 (حتى إذا تم تشخيص إصابتلك

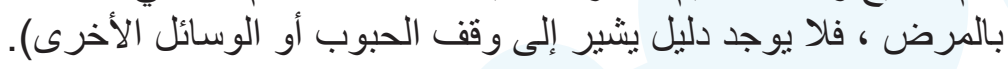

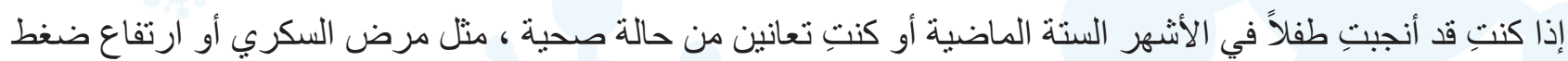

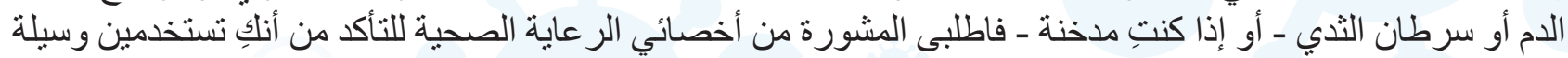
لتنظيم الأسرة مناسبة و آمنة للكِ.

وكذلك احرصى عند الذهاب لتلقى الخدمة فى اى منشاة طبية و خاصة اثناء فترة تركيب اللولب و الكبسولة ان ترتدى الكمامة.

\section{ا بـ هل تعتبر وسائل تنظيم الأسرة آمنة بالنسبة لمقدمى الذدمة عند تقديمها للمنتفعات؟}

يوجد قلق لاى بعض الأطباء و الممرضات من احتمال إصابتهم بالعدوى من المنتفعات عند تقديم خدمات تتظيم الأسرة

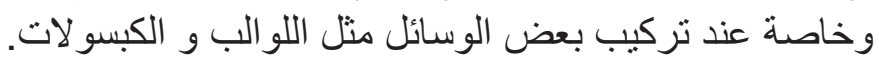

أن تقديم خدمات تتظيم الأسرة لا يشكل اى خطر زائد للطبيب فالمنتفعة التى تحصل على تللك الخدمات تعتبر كباقى

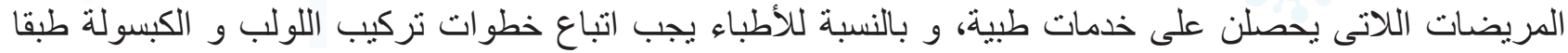

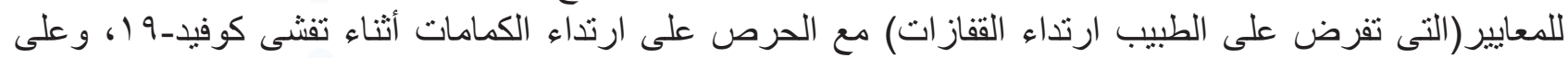

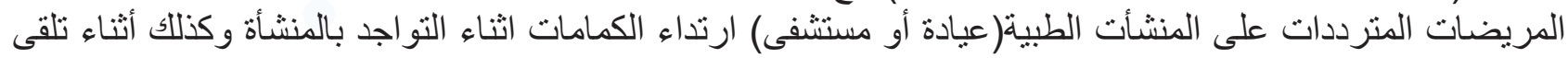
الخدمة و الكثف.

\section{r r- لا أستطيع الوصول إلى وسيلة تنظيم الأسرة التي أخترتها. ماذا تنصح؟}

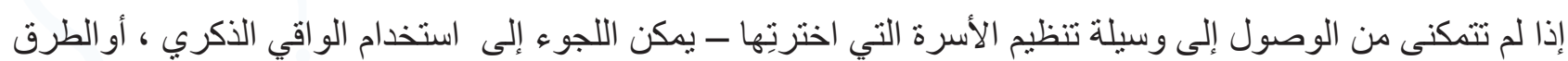

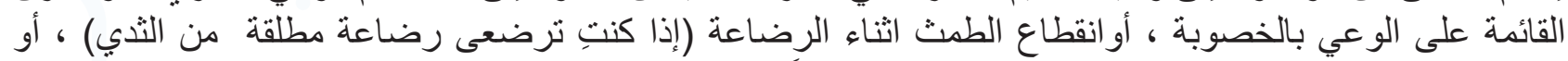

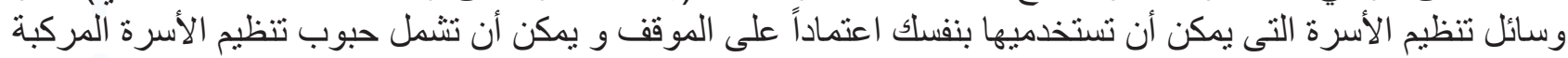

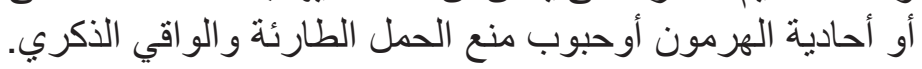

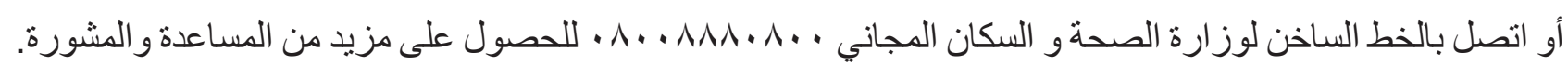
بسـ لماذا يعد توفير وسائل تنظيم الأسرة ، وكذلك خدمات ومعلومات تنظيم الأسرة ، أمرًا ضروريًاً خلال جائحة كوفيد- 9 (

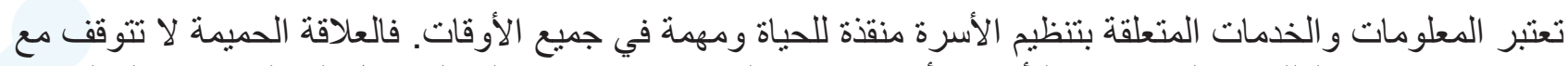

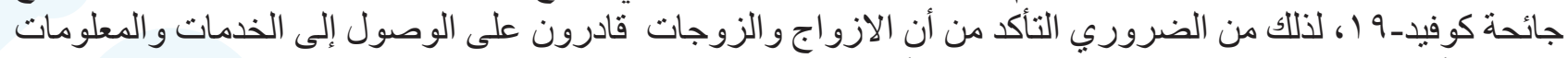
لبدء و / أو الاستمر ار في استخدام وسائل تنظيم الأسرة.

تساعد وسائل تنظيم الأسرة على منع حالات الحمل غير المخطط له بالأضافة إلى أن الو اقي الذكري يساعد على الحماية

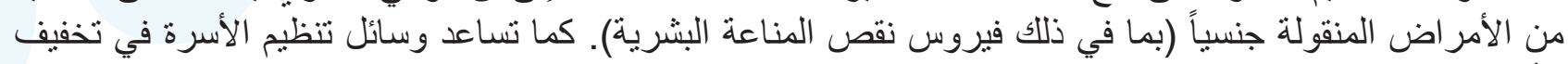

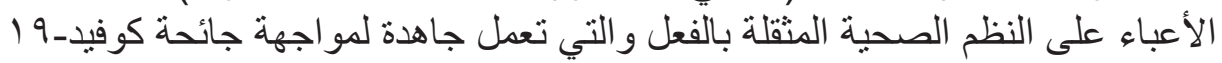

ع بـ أرغب في خلع أو استبدال الكبسولة أو اللولب ـ هل يمكنتي القيام بذلك أثناء جائحة كوفيد- 9 )

قد لا يتم إعطاء الأولوية لإز الة الوسائل طويلة المفعول مثل الكبسو لات أو اللولب ، بعد فترة الاستخدام الموصى بها

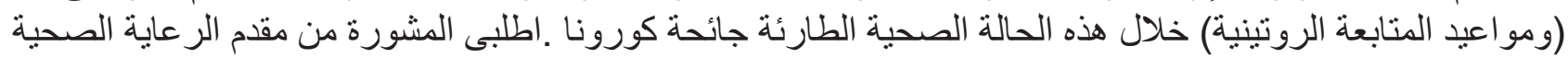

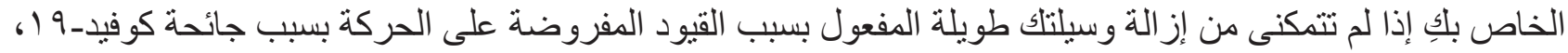

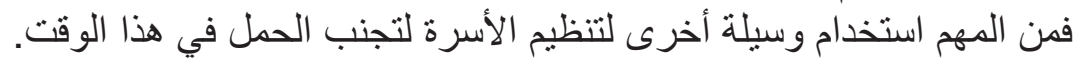


لا توجد مشاكل طبية ناجمة عن تأخير إزالة الوسائل طويلة المفعول مثل الكبسو لات أو اللولب. لا تحاولي إزالة وسيلة

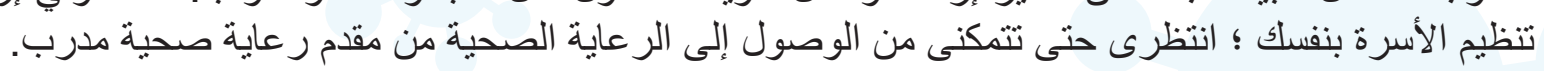

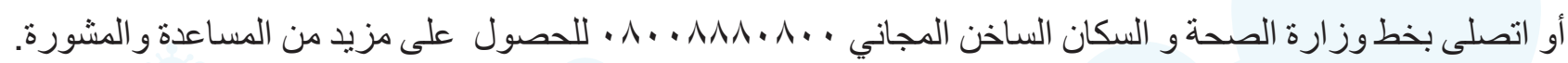
ه r- ما هي أفضل وسيلة لتنظيم الأسرة يمكن استخدامها أثناء جائحة كوفيد-9 1؟

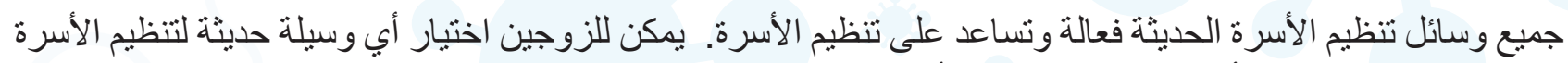

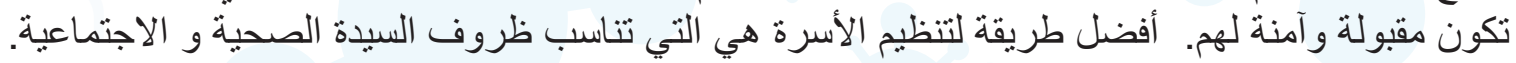

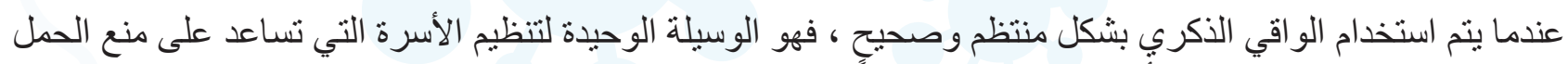

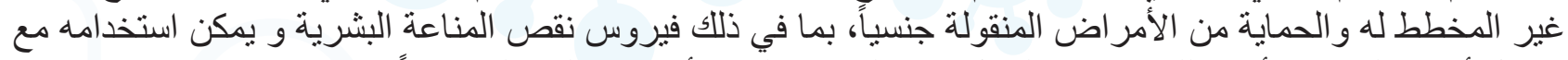

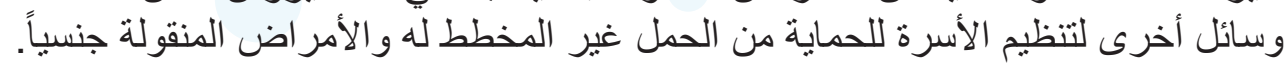

يمكن أن تمنع حبوب منع الحمل فى الحالات الطارئة ما يصل إلى 90٪ بـ من حالات الحمل عند تناولها في غضون هـ أيام

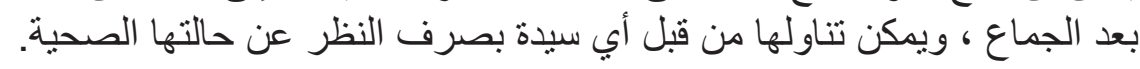

\section{ج سـ أريا تغييز وسيلة تنظيم الأسرة هل هذا ممكن أثناء جائحة كورونا؟}

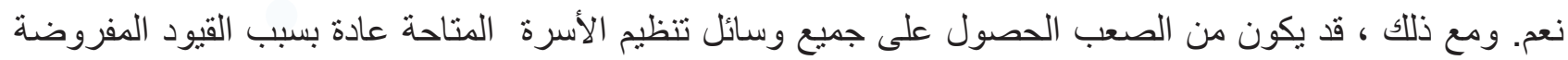

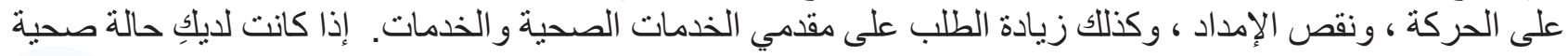

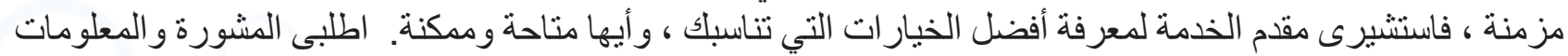

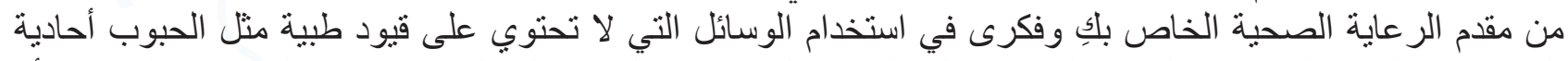

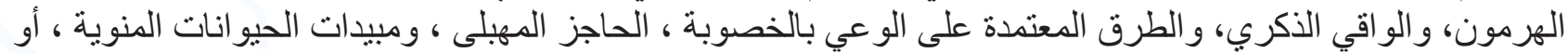

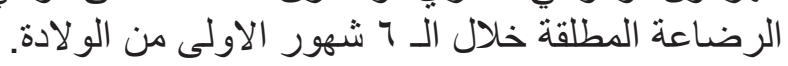




$$
\begin{aligned}
& \text { ثالثاً : كوفيد - } 19 \\
& \text { والحمـل والولادة والنغاس }
\end{aligned}
$$

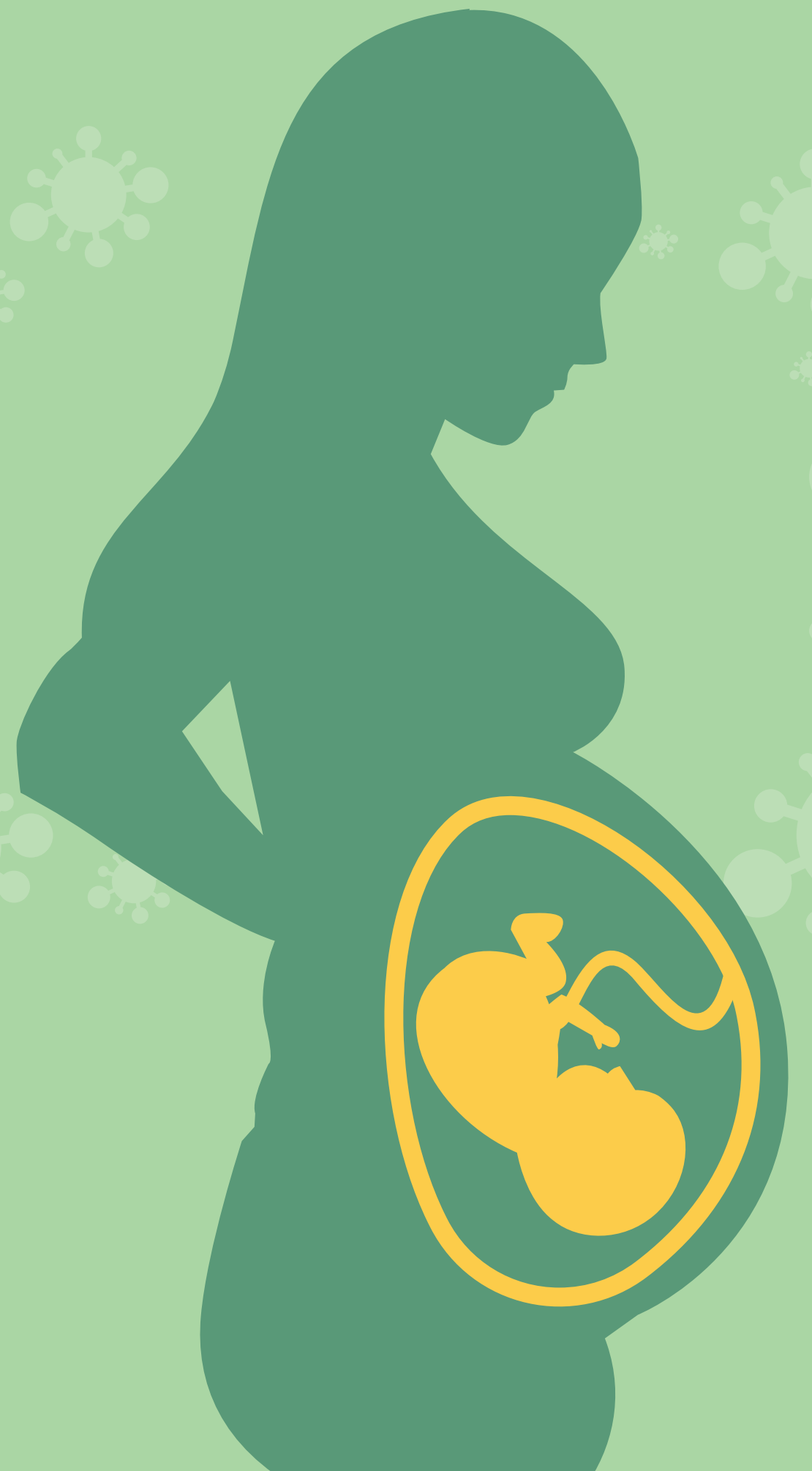


إن الحمل أثناء جائحة كوفيد-19 هو مسألة اختيار شخصي.

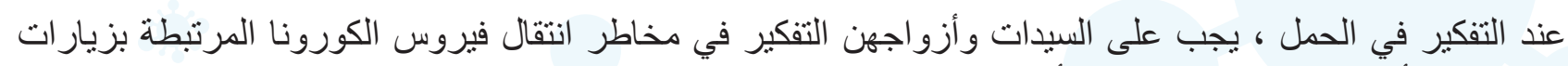

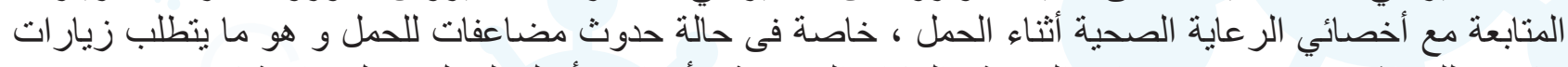

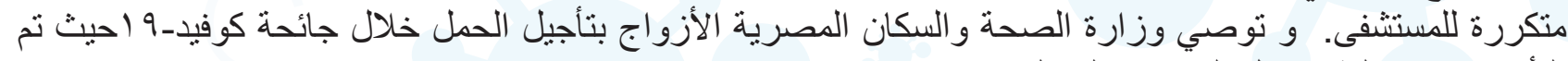
التأكد من احتمالية انتقال الفيروس إلى الجنين.

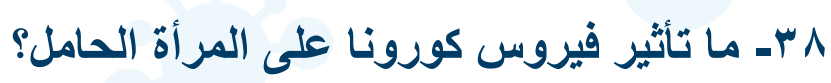

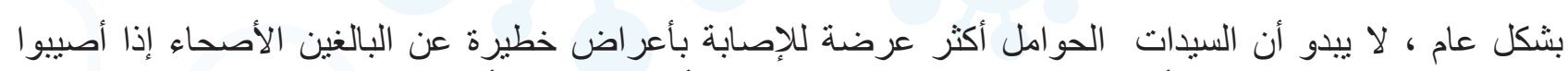

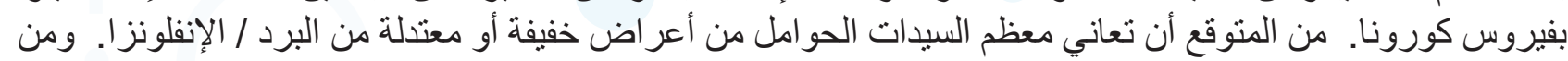
الأعر اض الأخرى ذات الصلة السعال و الحمى وضيق التنفس و الصداع ولعئ وفقدان حاسة الثم.

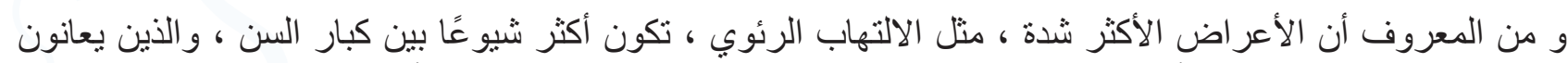

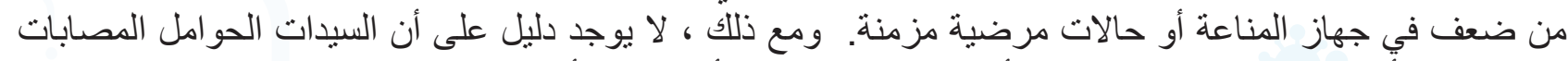

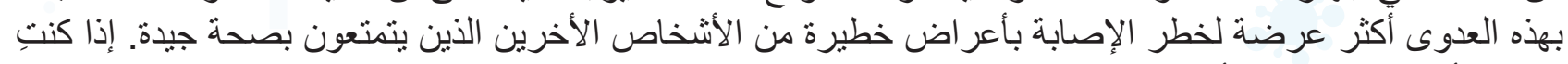

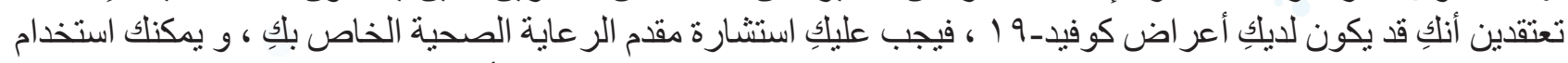

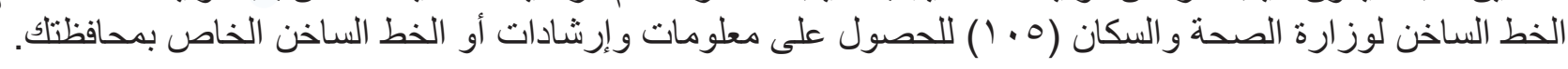

\section{9 سـ هل السيدات الحوامل أكثر عرضة للإصابة بأعراض خطيرة من كوفيد- 9 ا؟}

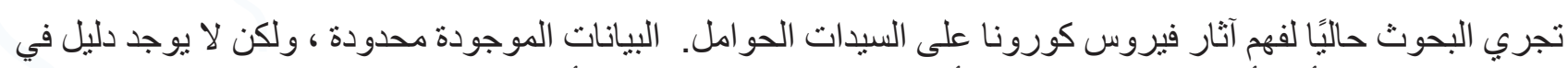

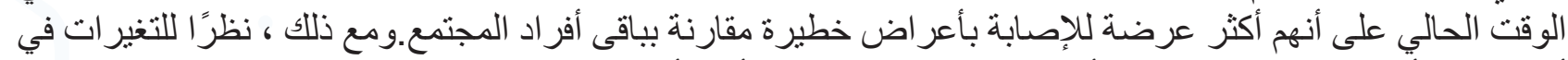

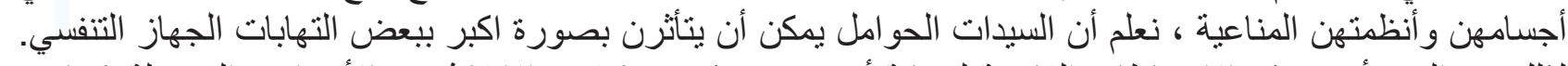

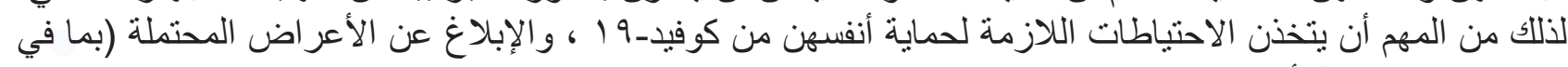

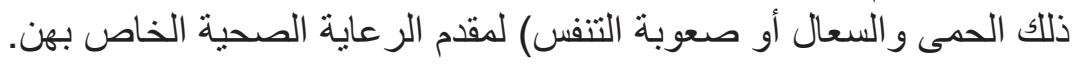
• عـ هل يمثل كوفيد- 9 ا خطرًا أعلى للإصابة بأعر اض خطيرة والوفاة للسيدات الحوامل مقارنة بالسيدات غير الحوامل? هل بمل

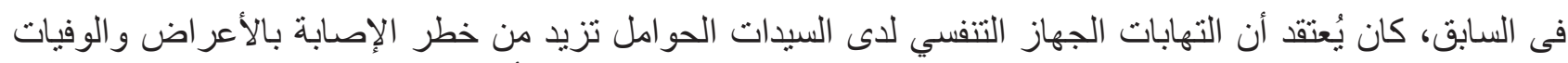

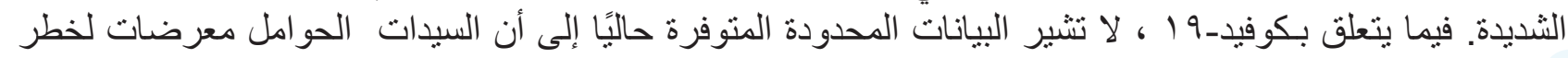

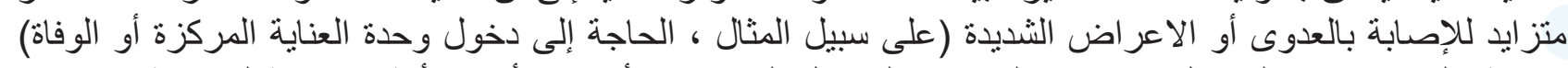

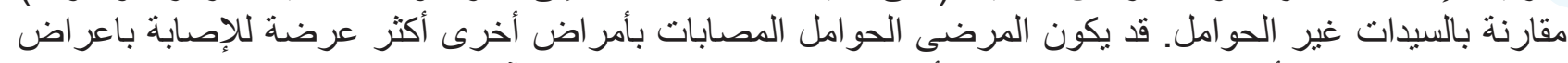

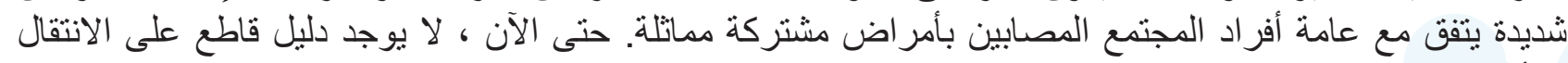
الر أسي لكوفيد- 9 (ا (الاتنقال للجنين).

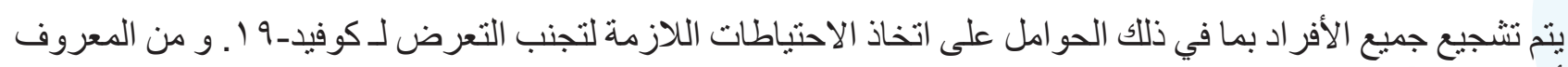

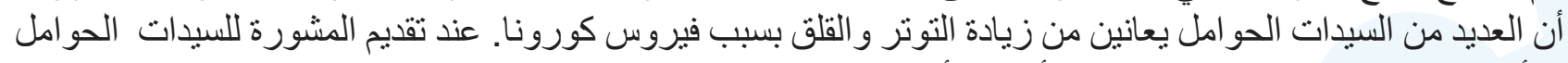

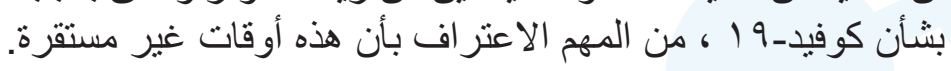

\section{| أـأنا سيدة حامل كيف يمكنتي حماية نفسي من كوفيد-9 19}

يجب على السيدات الحوامل اتخاذ نفس الاحتياطات لتجنب الإصابة بعدوى كوفيد-19 مثل الأشخاص الآخرين. يمكنك

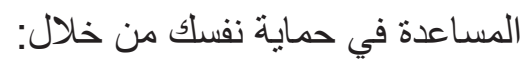


• • غسل اليدين باستمر ار بمطهر كحولي لليدين أو بالصابون والماء.

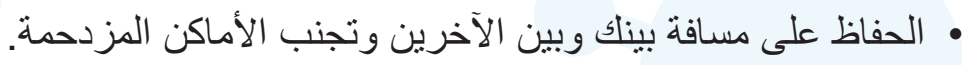
• • ت تجنب لمس العينين و الأنف و الفم.

• اتباع اجر اءات النظافة التنفسية. هذا يعني تغطية الفم والأنف بالكوع المنف المثني أو بمنديل ورقي عند السعال أو العطس. ثم التخلص من المنديل المستخدم على الفور.

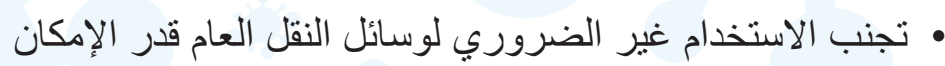

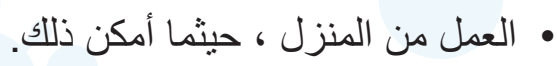

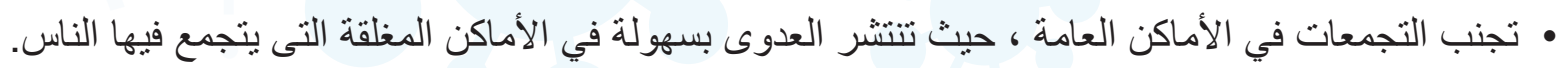

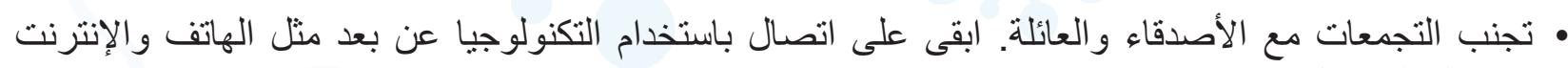

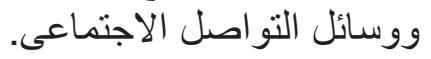
• باستخدام الهاتف أو الخدمات عبر الإنترنت للاتصال بطبيك أو الخدمات الأساسية الأخرى

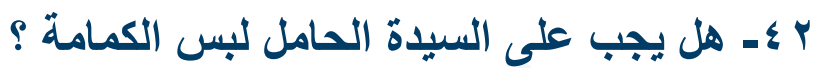

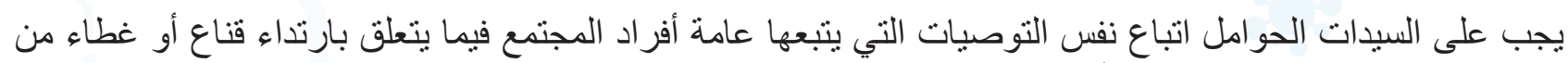

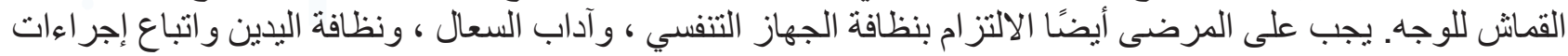

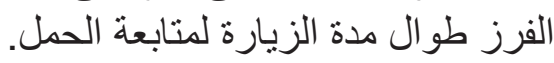

\section{ب عـ هل يمكنتى الذهاب إلى العمل اثناء الحمل خلال فترة جائحة كورونا؟ ماذا لو كنت أعمل في وظيفة

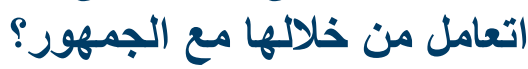

توصي الإرشادات الدولية بالعمل من المنزل للسيدات الحوامل اللاتي يمكنهن القيام بذلك. إذا كنتِ لا تسنطيعين العمل

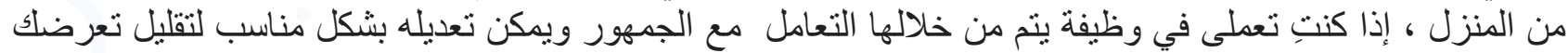

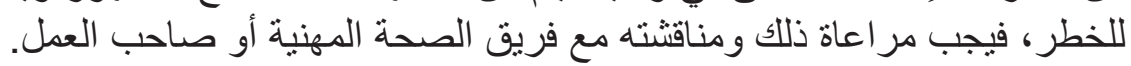

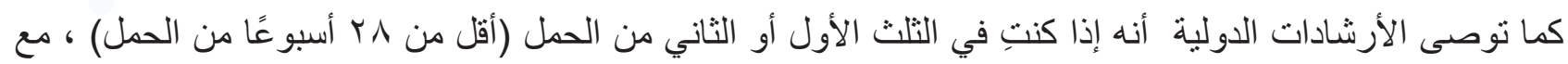

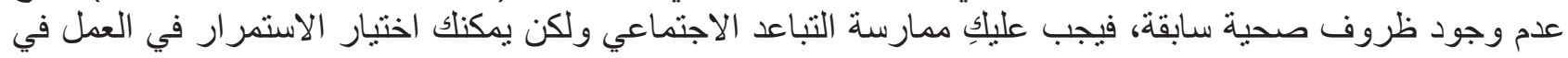

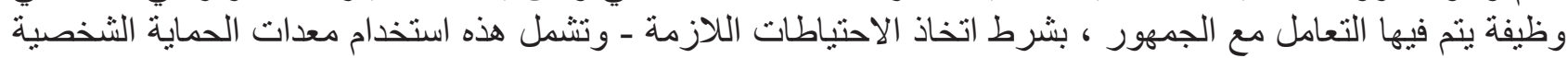
وتقييم المخاطر. (PPE)

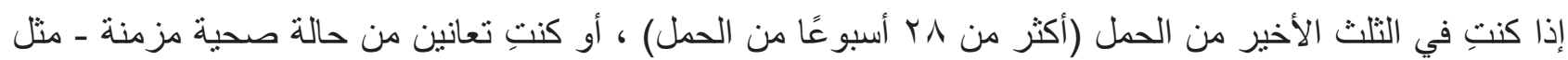

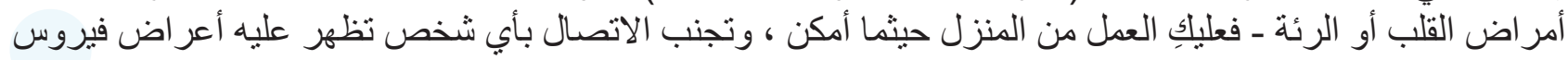

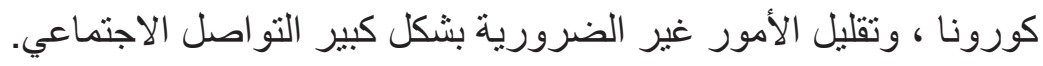

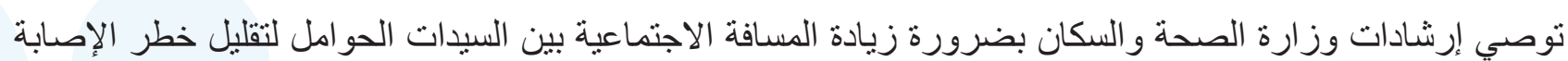

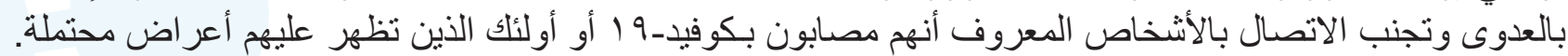

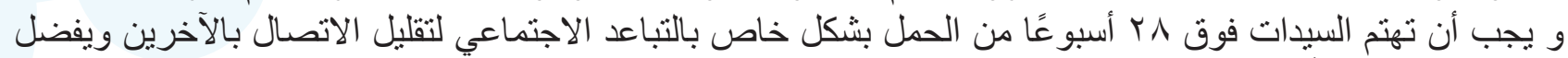

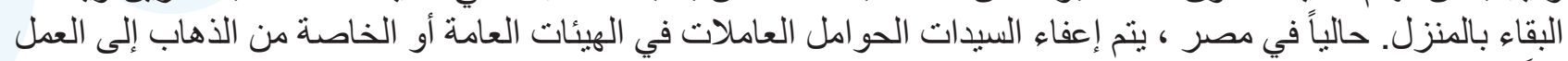
وفقًا للر أبي الطبي.

\section{ع ـ ـ ما هي النصيحة للسيدات الحوامل اللاتى يعملن فى المجال الصحى أثناء جائحة كوفيد- 9 ا؟}

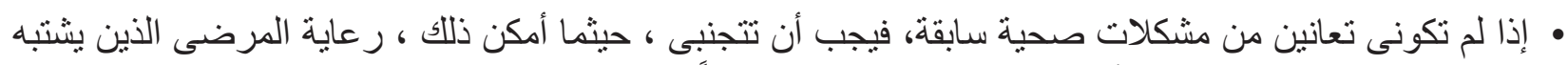

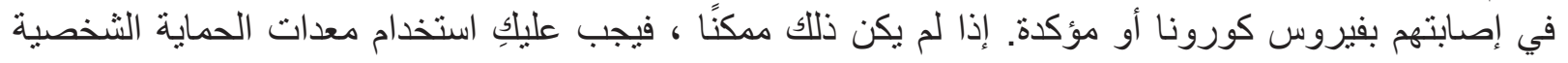


و التأكد من إجر اء تقييم شامل للمخاطر . يمكن للمر أة الحامل مو اصلة العمل فقط عند تامينها من المخاطر .

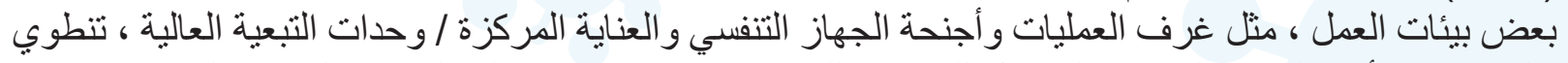

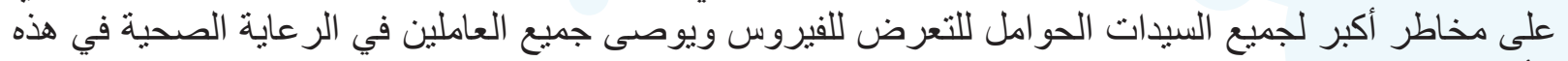

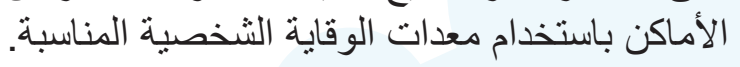

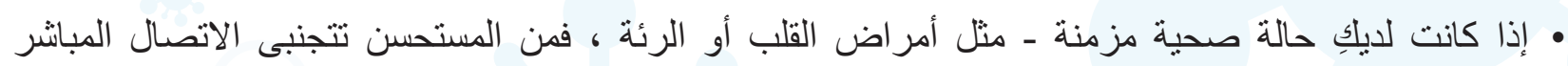

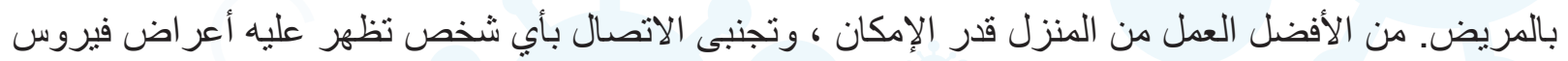

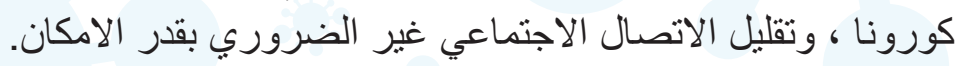
إذا لم يكن ذلك ممكنًا ، يوصى باستخدام معدات الوقاية الشخصية المناسبة.

\section{ه ــ هل يزيد الحمل من الحاجة إلى العناية المركزة في حالة الإصابة بعدوى كوفيد-9 1؟}

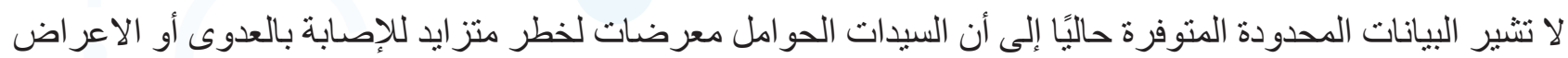

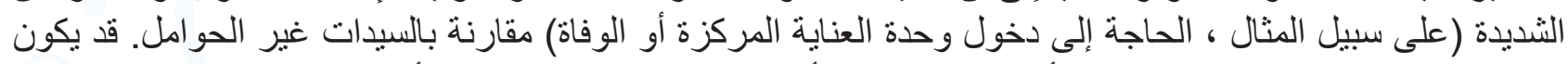

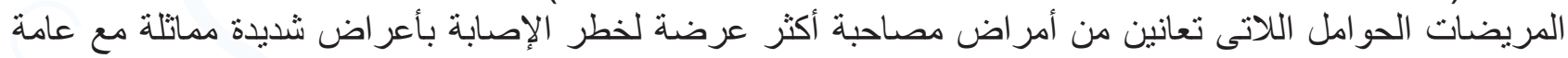

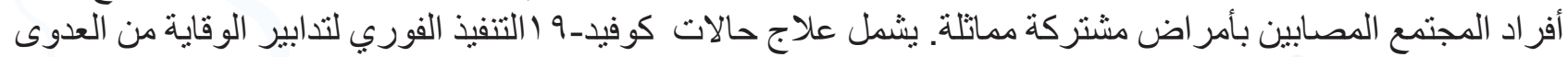

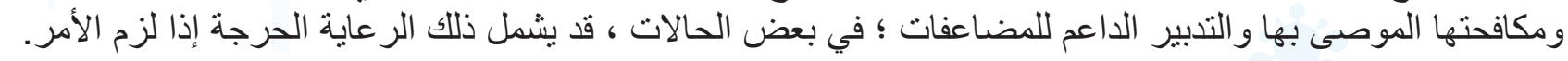

إذا كان الحمل باه مضاعفات بسبب مرض خطير ، فيجب أن تتم رعاية السيدة الحامل بالمستشفى مع خدمات التوليد ووحدة العناية المركزة للبالغين.

إن حالة كوفيد-9 1 وحدها ليست بالضرورة سبيًا لنقل السيدات الحوامل المصابات بكوفيد-9 1 المشتبه به أو المؤكدة ،

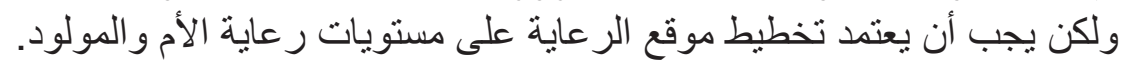

\section{7 צ ـ كيف يمكنتي حماية صحتى النفسية أثناء الجائحة؟}

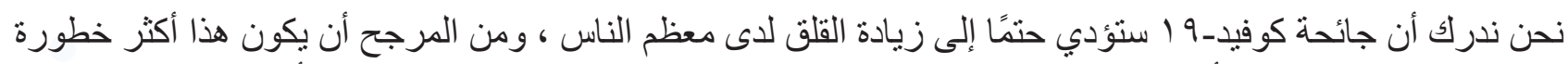

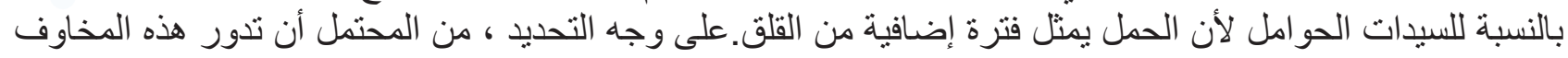
حول:

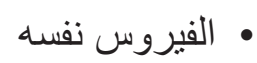

• تأثثير العزلة الاجتماعية مما يؤدى إلى انخفاض الدعم من الأسرة والأصدقاء بشكل عام

• • إمكانية انخفاض دخل الأسرة

• تغيير ات كبيرة في خدمات رعاية الحمل ، بما في ذلك تغيير المو اعيد والتحول من الاتصال وجهاً لوجه إلى الاتصال

الـهاتفي.

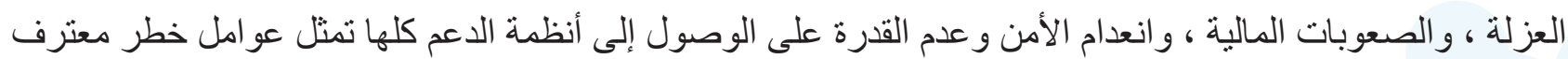

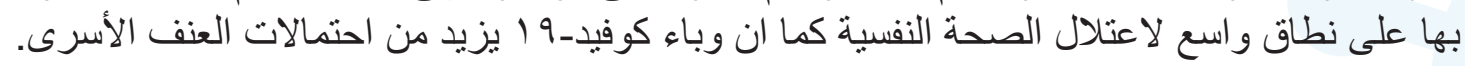

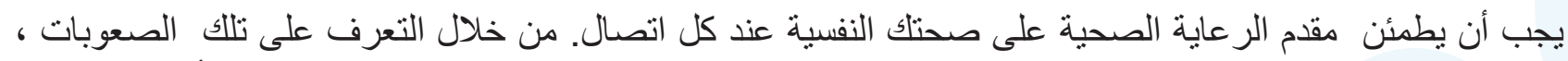

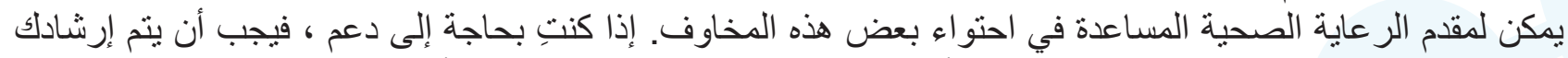

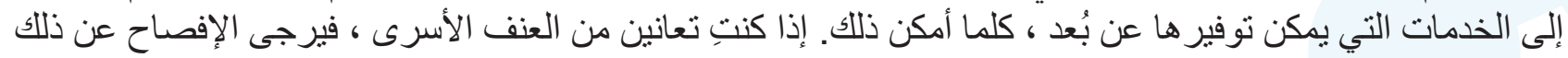

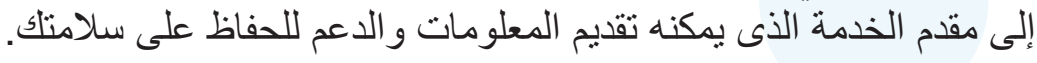


يجب نصح السيدات الحوامل بحضورزيار ات رعاية الحمل ، على الرغم من نصحهن بالحفاظ على التباعد الاجنماعي.

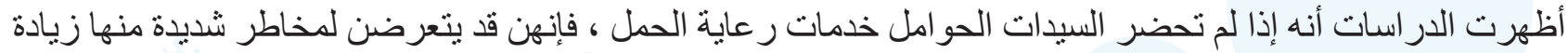

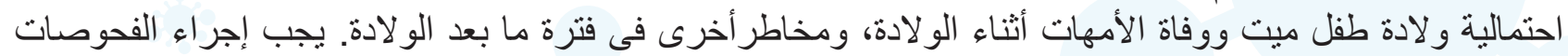

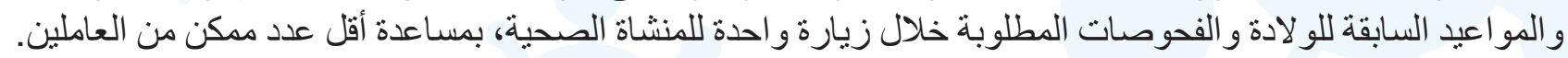

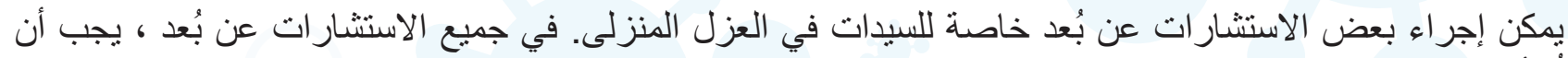

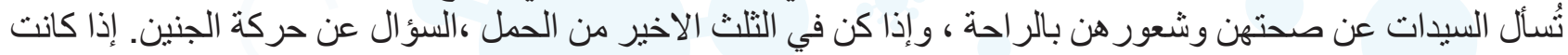

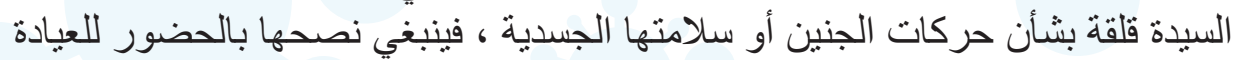

خلال فترة وباء كوفيد-9 1 ، يجب الحصول بشكل روتيني من جميع السيدات الحوامل اللائي يحضرن لزيار ات متابعة

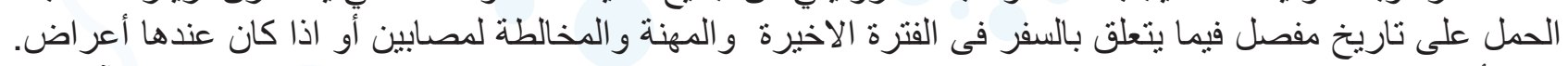

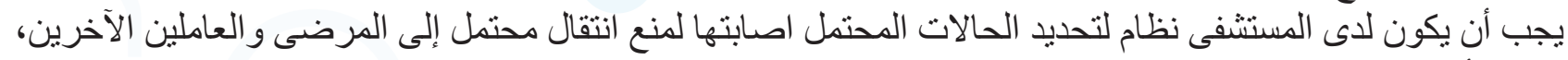

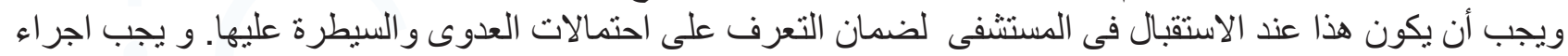

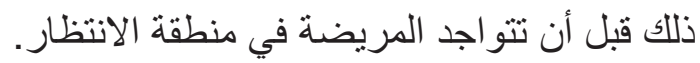

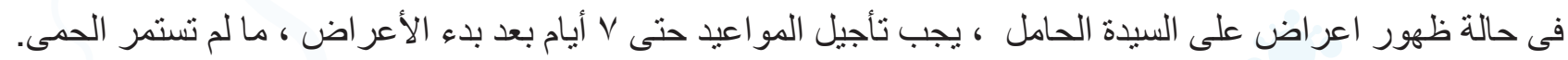

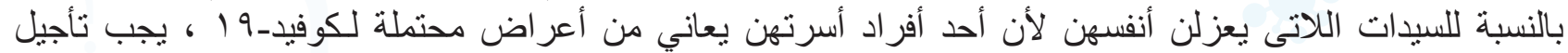

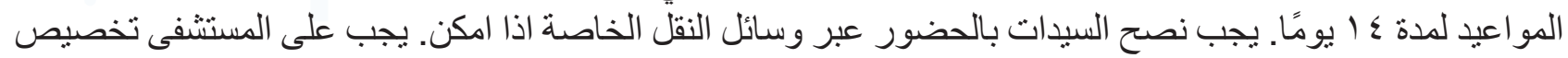

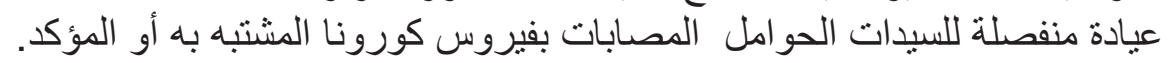

\section{1 § - هل تحتاج السيدات الحوامل اللاتى يعانين من اصابة مؤكدة او المشتبه فى اصابتهن بكوفيد-19 19

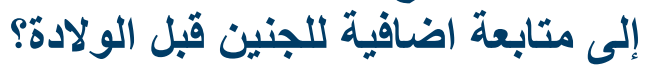

فى حالة اصابة السيدة الحامل بكوفيد-9 1 ، يجب أن تكون متابعة الجنين مماثلة لتلك المقدمة لأي سيدة حامل مريضة

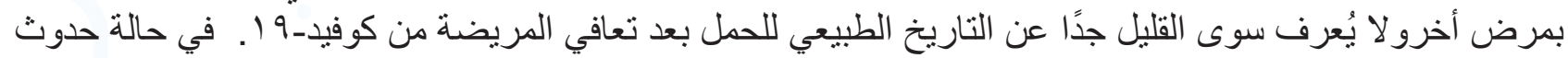

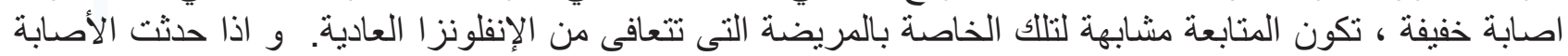

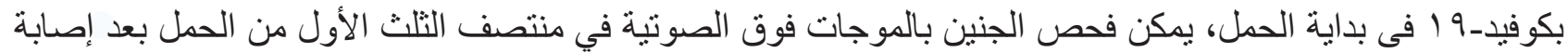

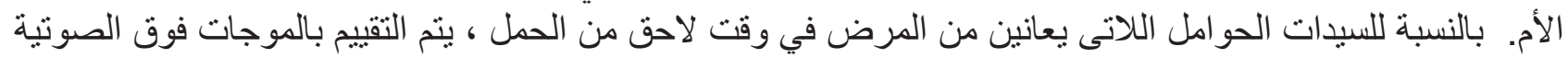

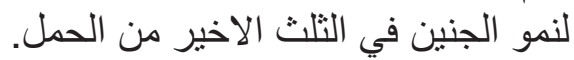

\section{9 ـ ـ هل يجب أن تستمر السيدة الحامل في أخذ تطعيمات الحوامل أثناء جائحة كوفيا-ه 19}

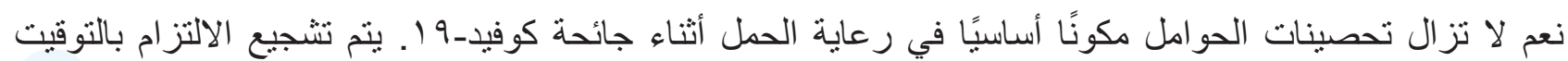

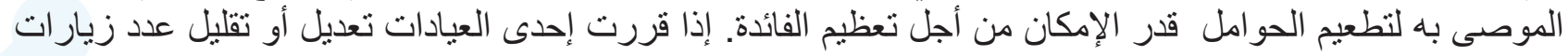

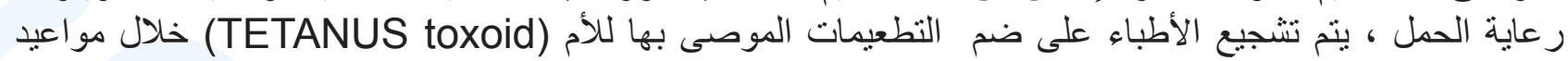

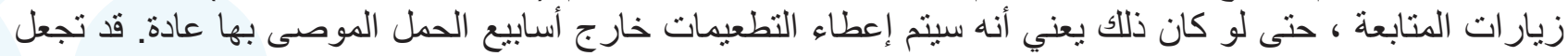

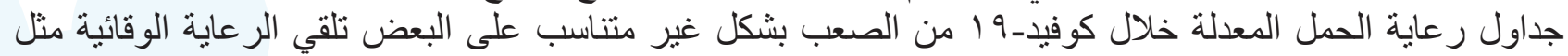

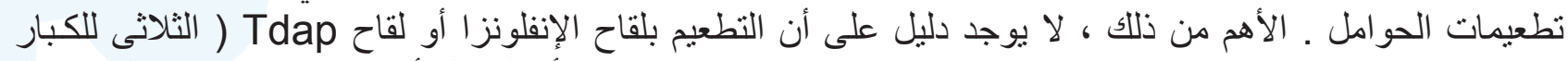
(tetanus, diphtheria and pertussis كوفيد-9 1 أو مضاعفاته.

على غرار الأمر اض المعدية الأخرى ، إذا اشتبهت سيدة بعد الولادة بأصابتها بكوفيد-9

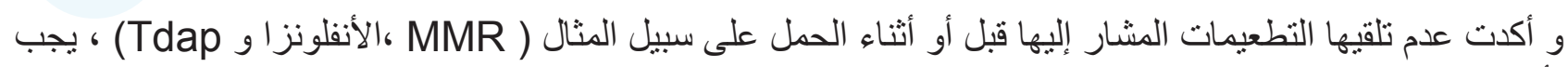
تأجيل هذه التطعيمات حتى تتعافى تمامًا من المرضات لتصل 
• هـ ماذا أفعل إذا اعتقدت أنني مصابة بفيروس كورونا أو تعرضت له؟

$$
\text { إذا كنتى حامل وكان لديكى: مرادة }
$$

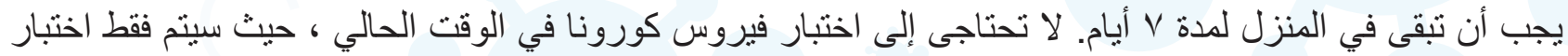

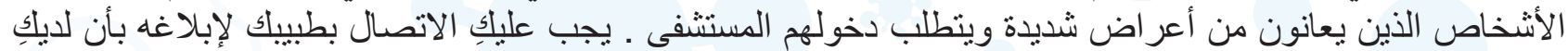

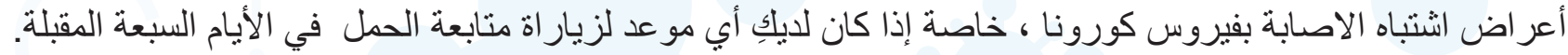

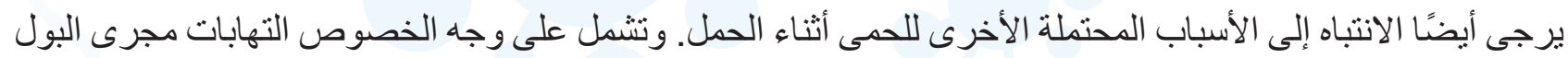

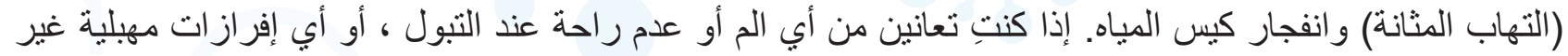

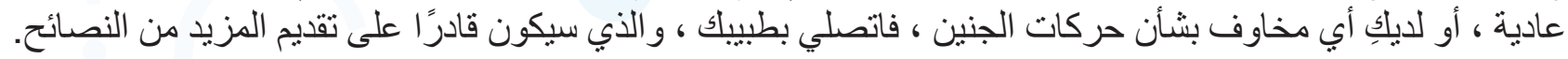

إذا كنتِ مصابة بكوفيد-9 19 ، ففى الاغلب لن تعاني من أعراض خطيرة و ستكون الاعر اض لايكِ خفيفة وستعافين منها

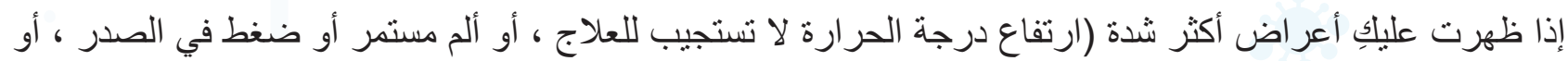

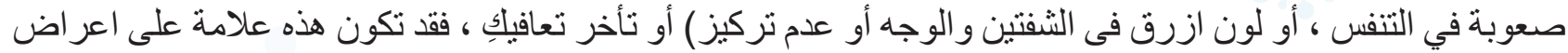

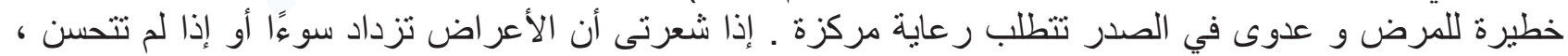

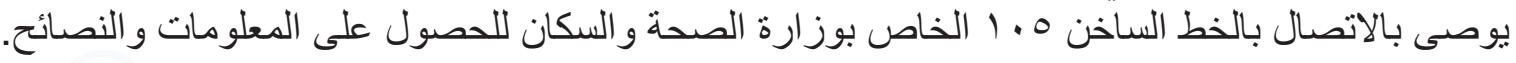
إذا كانت لديكِ مخاوف بشأن صحتلك و صحة جنينك خلال فترة العزلة في المنزل ، فاتصلى بطبيبك الذى سيقدم لكى

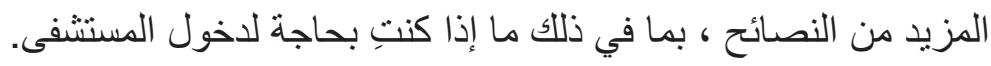

\section{0ـ كيف سيتم اختباري لفيروس كورونا؟}

تتطور عملية تثخيص الإصابة بفيروس كورونا بشكل سريع في الوقت الحالي ، يتم اختبار فقط الأشخاص الذين يعانون من أعراض حادة ويحتاجون إلى دخول المستثفى.

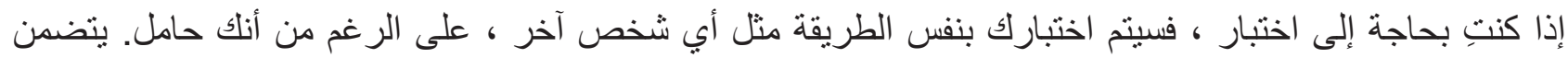
الاختبار حاليًا أخذ مسحات من فمك أو أنفاك. قد يُطلب منلك أيضًا سعال البلغي و هو خليط من اللعاب و المخاط.

\section{r بـ ماذا أفعل إذا كاتت نتيجة اختبار فيروس كورونا إيجابية؟}

إذا كانت نتيجة اختبار فيروس كورونا إيجابية ، يجب عليكِ الاتصال بطبيك لإبلاغه بتثخيصك. إذا لم تكن لديكِ أعر اض أو لديكِ أعراض خفيفة ، فسوف تتصحين بالعزل في المنزل و أخذ البروتوكول العلاجى المناسب

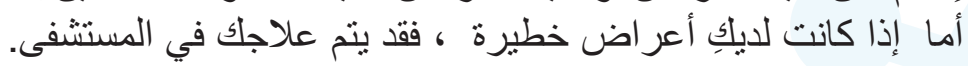

\section{بهـ ما تأثير فيروس كورونا على الجنين فى حال تثخيص إصابتي بالعدوى؟}

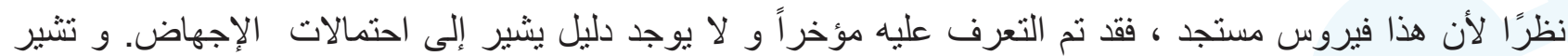

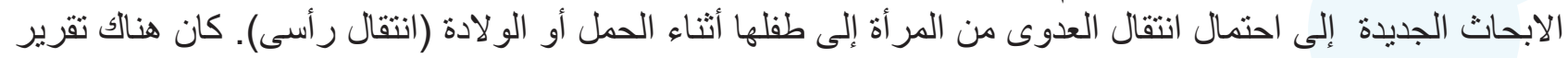

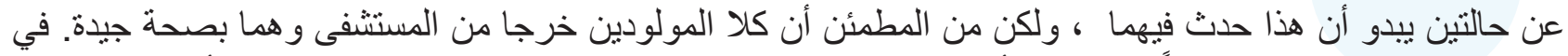

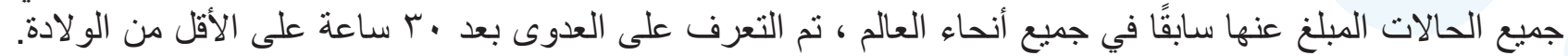

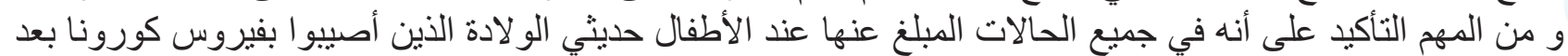
الو لادة بفترة وجيزة ، كان الطفل بصحة جيدة. 
وبالنظر إلى الأدلة الحالية ، فإنه إذا كنتِ مصابة بالفيروس ، فمن غير المحتمل أنه سوف يتسبب في مشاكل في نمو طفلك.

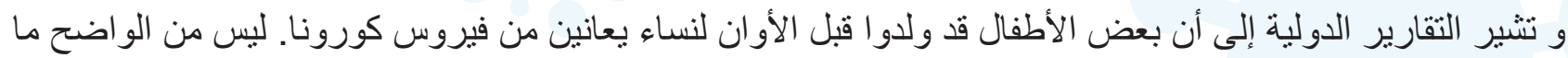

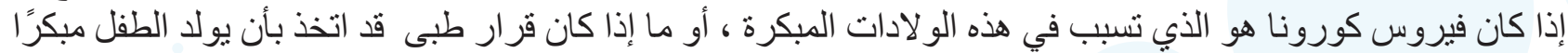

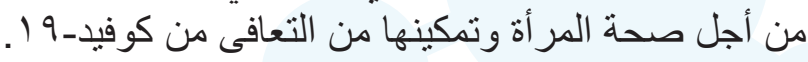

\section{ع هـ لماذا يُطلب مني العزل المنزلى (بدلاً من تقليل الاتصال الاجتماعي)؟}

قد تتصحين بالعزل في المنزل للأسباب التالية: • لديكِ أعر اض الاصابة بفيروس كورونا ، مثل ارتفاع درجة الحرارة أو سعال مستمر.

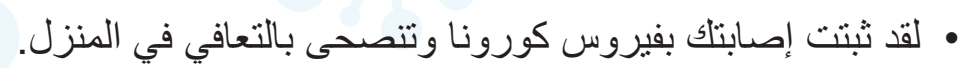

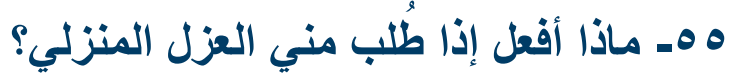

يجب على النساء الحوامل اللواتي نُصحن بالعزل في المنزل البقاء في المنزل وتجنب الاتصال بالآخرين لمدة V أيام إذا

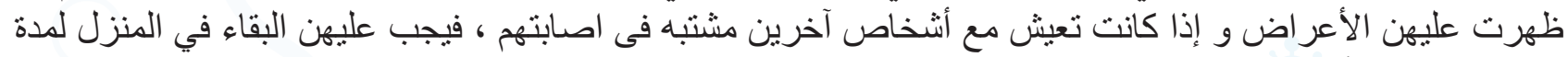

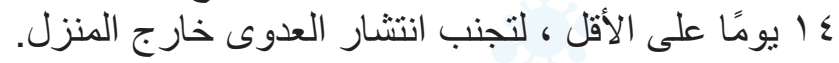

توصي إرشادات وزارة الصحة والسكان بشأن العزل المنزلي حاليًا الأشخاص بما يلي:

$$
\text { • • البقاء في المنزل و عدم السماح للزوار . }
$$

• فصل أنفسهم عن أفر اد أسر هم الآخرين قدر الإمكان ، باستخدام المناشف و الأواني الخاصة بهم وتناول الطعام في

أوقات مختلفة.

• الاستعانة بالأصدقاء أو العائلة أو خدمات التوصيل لمساعدتهم فى الحصول على احتياجاتهم الثرائية ، ولكن نصحهم

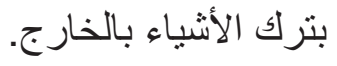

\section{צهـ كيف ستثم متابعتى و رعايتي بعد التعافي من فيروس كورونـا؟}

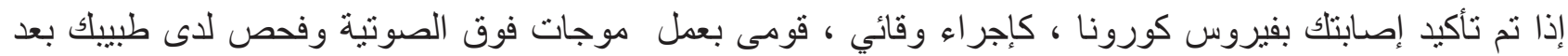

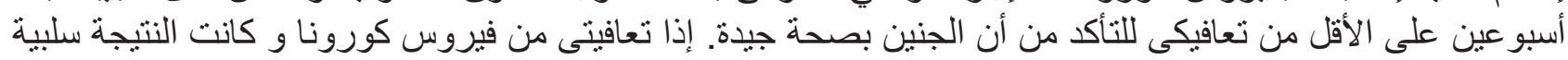
للفيروس قبل دخو للك المخاض ، فلن ينأثر مكان وكيفية الو لادة بمرضك السن السابق.

Vهـ ماذا أقعل إذا شعرت بتوعث أو كنت قلقة على جنينى أثناء العزل المنزلى؟

تتصح السيدات الحوامل المعزولات بالمنزل بعدم حضور زيار ات متابعة الحمل إلا في حالة الحاجة إلى رعاية طبية عاجلة.

إذا كان لايلكِ مخاوف بثأن صحتلك أوصحة جنينك خلال فترة العزل ، فاتصلى بطبيك. سوف يقدم المزيد من النصائح ، بما في ذلك ما إذا كنت بحاجة إلى دخول المستشفى.

إذا تم نصحك بالذهاب إلى المستشفى ، بُطلب من السيدات الحوامل التنقل بوسائل النقل الخاصة اذا امكن. ^هـ هل هناك مشورة إضافية اثناء متابعة الحمل او بعد الولادة التي يجب مراعاتها فيما يتعلق بـ كوفيد- 9 اهو نعم. قد يكون من الضروري تقديم مشورة خاصة استباقية للسيدات الحوامل فيما يتعلق بما يلي: 
• أي تغيير ات محتملة في مدة الإقامة في المستشفى و الر عاية بعد الو لادة. • أفضل طريقة للتو اصل مع طبيبها الخاص ، خاصة في حالة الطوارئ. • • علامات و أعر اض المخاض ومتى يجب استدعاء الطبيب. • أبي نصائح خاصة لتغذية المولود. • مر اجعة طبيب الأطفال أو طبيب الأسرة فيما يتعلق بزيار ات الأطفال حديثي الولادة لأن أطباء الأطفال أو أطباء

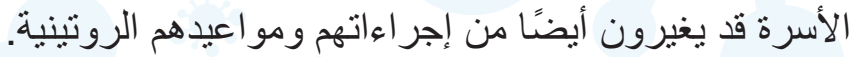

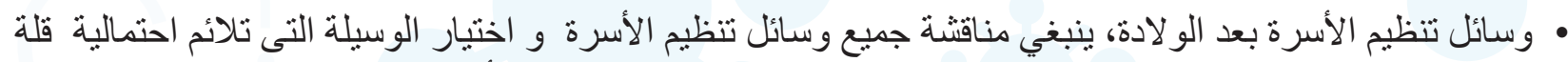

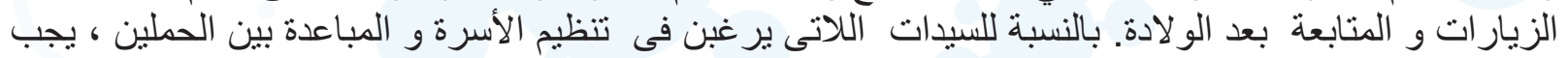
على الأطباء مناقثنة المز ايا الإضافية لوسائل تنظيم الأسرة طويلة لإنة المفعول (LARC)

\section{هــ مـا الذي أحتاج إلى معرفته قبل موعد الولادة؟}

تقدم وزارة الصحة و السكان المصرية للسيدات الحوامل خمس نصائح لمساعدتهن على الولادة الآمنة أثناء جائحة

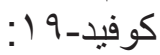

$$
\text { • اختارى مستشفى يطبق إجر اءات مكافحة العدوى }
$$

• اتبعي نصائح طبيبك لتجنب الولادة المبكرة لتقليل احتمالات دخول حديثي الولادة إلى حضانات حديثي الولادة ومخاطر العدوى ناتح • قللى من عدد الأشخاص الذين ير افقونلكِ إلى المستشفى إلى شخص و احد

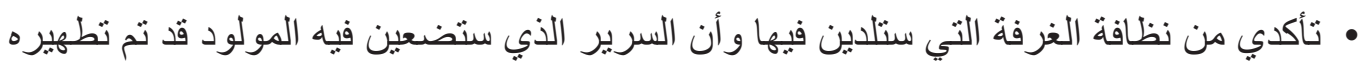

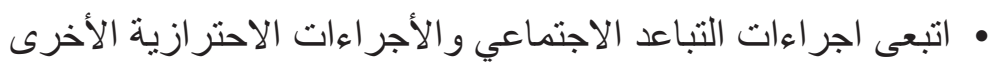

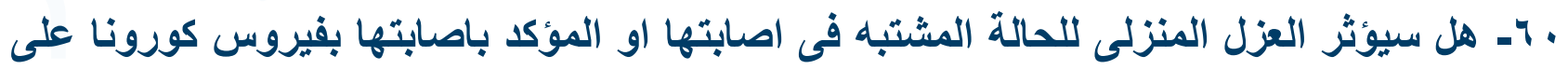
مكان الولادة" مل بلو

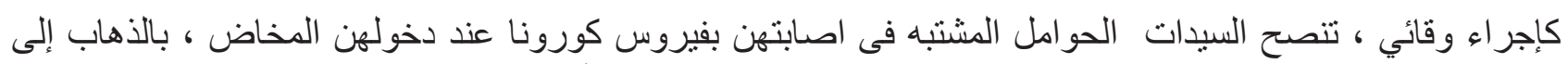

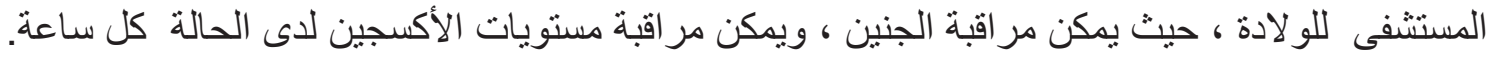

المر اقبة المستمرة للجنين هي للتحقق من كيفية التعامل مع الجنين فى الولادة. حيث لا يمكن إجراء المر اقبة المستمرة للجنين إلا في المستشفى ، حيث يتو الدئ الأطباء.

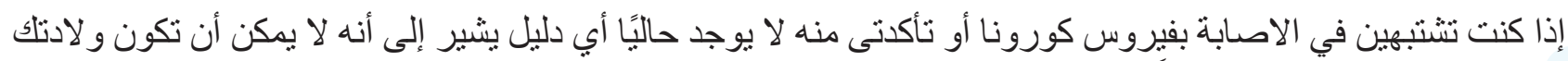

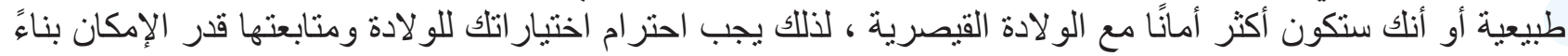

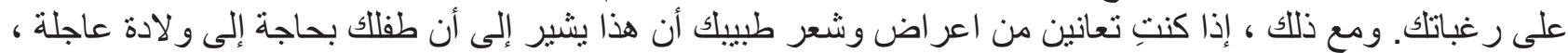
فقد يوصى الطبيب بالو لادة القيصرية. لا بوجد دليل على أن السيدات المشتبه فى اصابتهن أو المؤكدة اصابتهن بفيروس كورونا لا يمكن أن يحصلن على تخديرفي العمود الفقري.

في مصر ، إذا كانت السيدة الحامل اثناء و لادتها تعاني من الحمى ، يتم علاجها كحالة من حالات الانتان (sepsis ) أنثاء

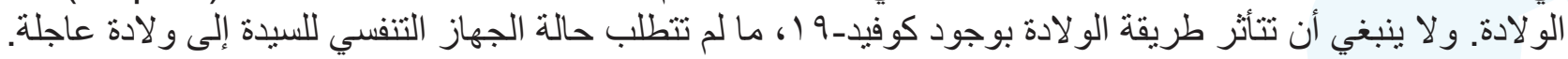

\section{1 ا ـ هل يجب فحص المرضى من السيدات الحوامل قبل القدوم للمستثنفى؟}

يجب على أطباء الرعاية الصحية التفكير في طريقة بديلة للمتابعة الروتينية للسيدات الحوامل (مثل الهاتف والرعاية

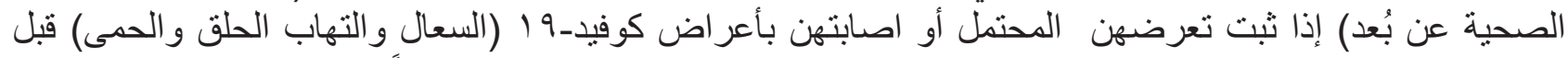

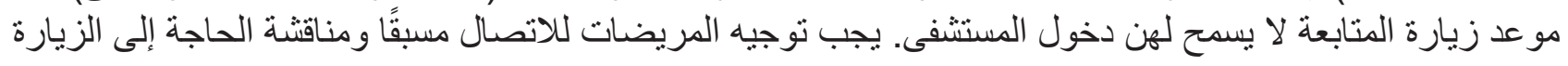




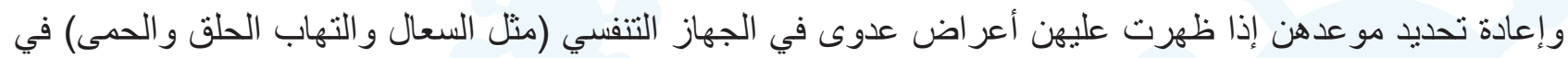

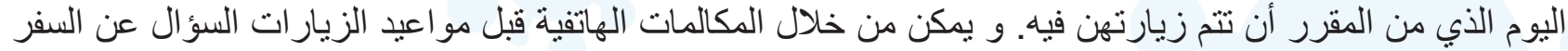

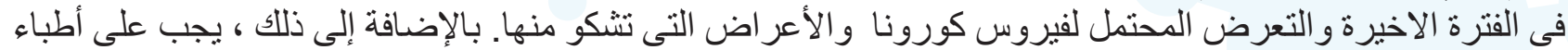

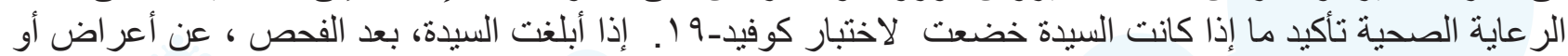

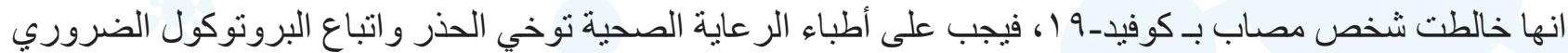
لأنه يمكن ان ينأثر أو يحتمل أن تكون مصابة بالفيروس.

r Y - هل تحتاج السيدة الحامل المشتبه فى اصابتها أو المؤكدة الأصابة بفيروس كورونا إلى الولادة

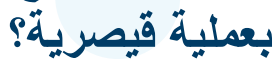

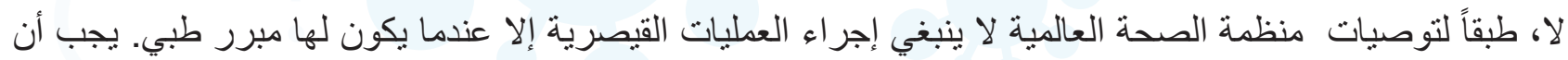
يعتمد أسلوب الولادة على ظروف السيدة الصحية و النفسية ويستند إلى تفضيلات السيدة جنبًا إلى جنب مع مؤشرات الو لادة.

\section{با - كيف يمكن الوقاية من التخثر للحوامل وما بعد الولادة فى حالة الاصابة او الاثثباه فى الاصابة بكوفيد- 19}

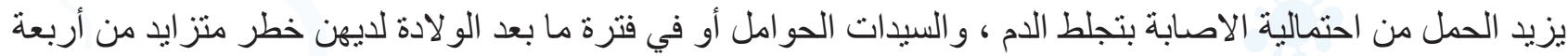

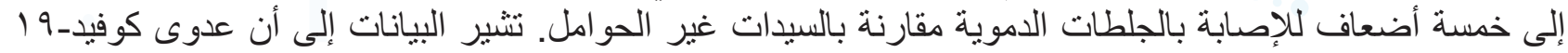

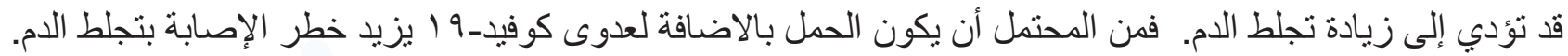

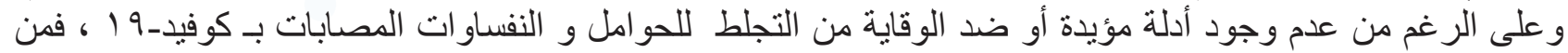

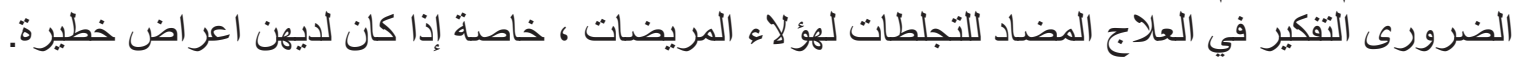

ع 7- هل يجب اعتبار الحمى أثناء الولادة علامة محتملة للاصابة بكوفيد-9 1؟

إذا كانت السيدة تعاني من الحمى ، فابحث عن سبب الحمى و عالجها كحالة من حالات الأنتان (sepsis ) أثناء الو لادة

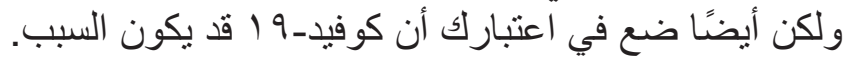

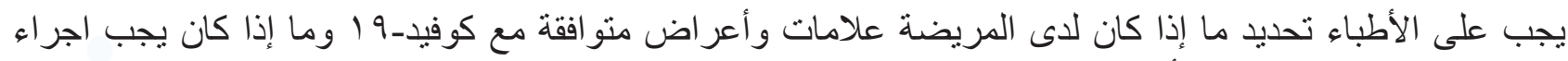

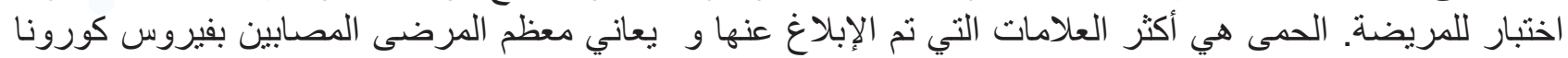

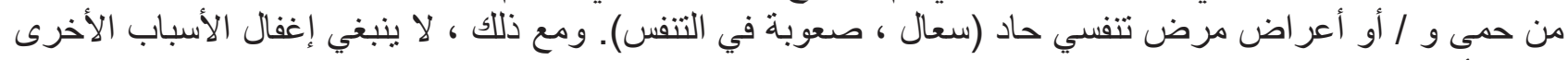
ل ألحمى أثناء الو لادة.

ه 1 - هل يمكن للسيدات المصابات او المشتبه فى اصابتهن بفيروس كورونا أن يرضعن اطفالهن؟

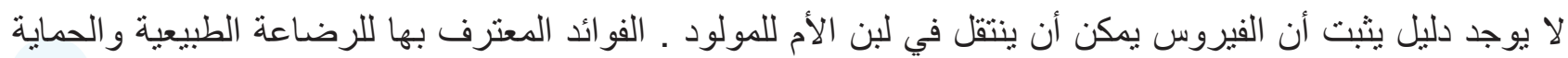

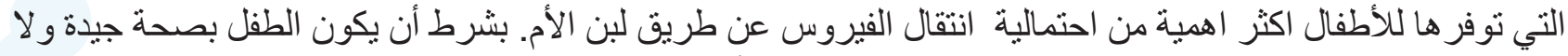

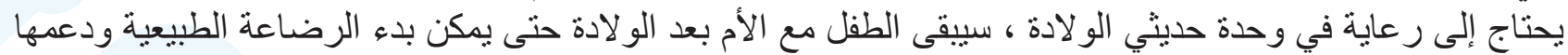
إذا رغبت في ذلك. و عندما تقوم الأم بارضار لإناع الطفل ، ينصح اتباع الاحتياطات التالية: • غسل اليدين بشكل متكرر بالماء و الصابون أو استخدام الكحول لفرك اليدين وخاصة قبل لمس الطفل.

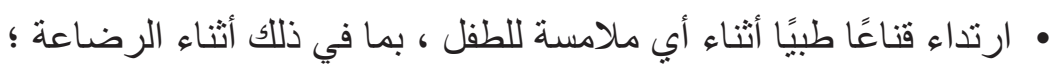

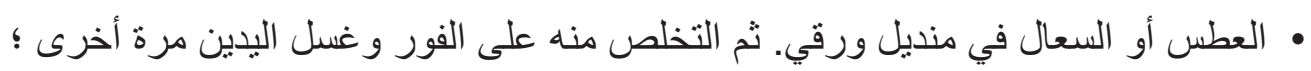
• ت تنظيف وتعقيم الأسطح التي تلمسها الأمهات بشكل روتيني. • من المهم استبدال الأقنعة الطبية بمجرد أن تصبح رطبة والتخلص منها على الفور. لا ينبغي إعادة استخدام الأقنعة

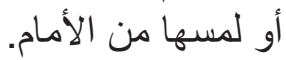

• اتباع توصيات تنظيف المضخة فى حال استخدام مضخة اللبن. 
7 7 ـ لقد تأكدت أو اشتبهت في اصابتى بفيروس كورونا ولم أتمكن من الرضاعة الطبيعية متى يمكنتي

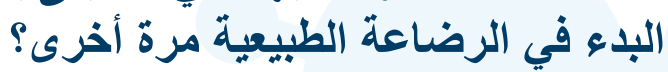

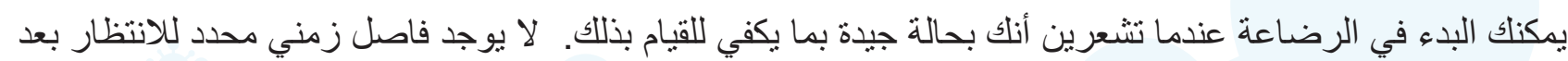

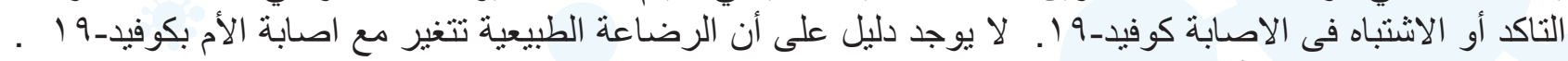
يجب على طبيب طفلك أو مستشاري الرضاعة الطية الطبيعية دعمك لمعاودة الرضاعلة الرضاعة الطبيعية. V V - هل يمكنتي لمس طقلي حديث الولادة و حمله إذا كنت مصابة بـ كوفيد- 19 نعم . يساعد الاتصال الوثيق و الرضاعة الطبيعية المطلقة المبكرة على نمو الطفل. يجب أن يتم دعمك ومساعدتلك على لى

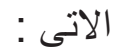

• الرضاعة الطبيعية بأمان ، مع الحفاظ على نظافة الجهاز التنفسي ؛ • ثنتي طفلك حديث الو لادة بحيث بلامس جلده مع جلدك

• مشاركي طفلك بالغرفة

• يجب غسل يديكِ قبل لمس طفلك وبعده والحفاظ على نظافة جميع الأسطح.

1 ז- هل سيخضع طقلي لفحص فيروس كورونا؟

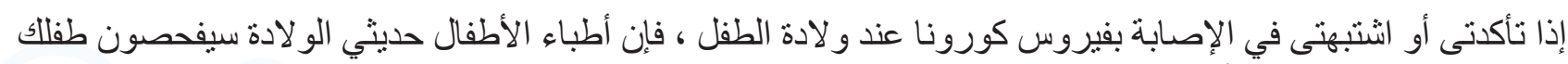

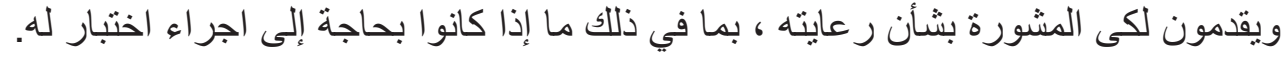

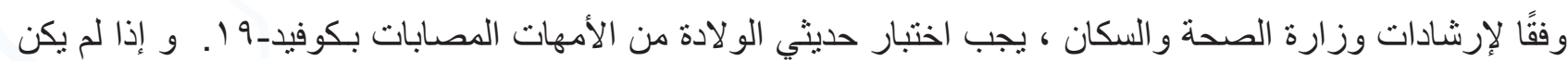

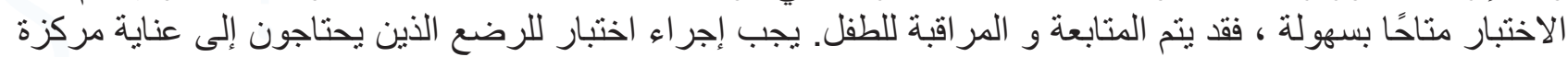

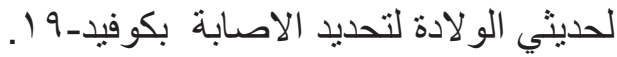

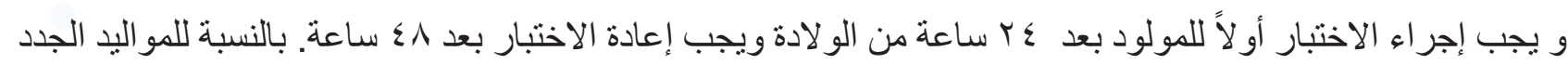

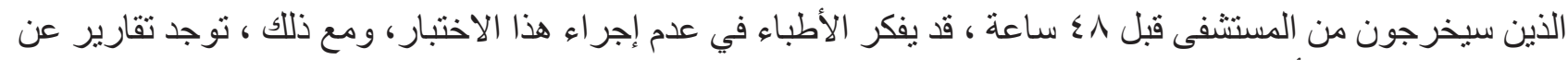

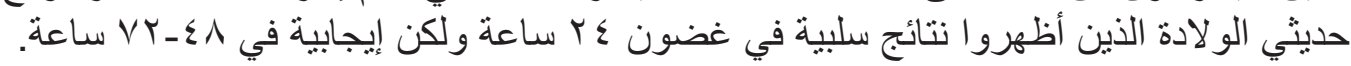

\section{7 - بعد الولادة هل هناك خطر متزايد علي أو على طفلي من الاصابة بفيزوس كورونا؟}

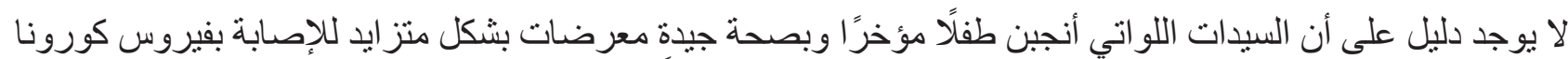

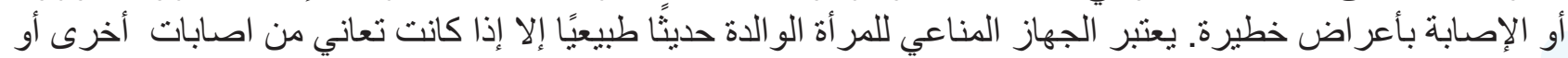

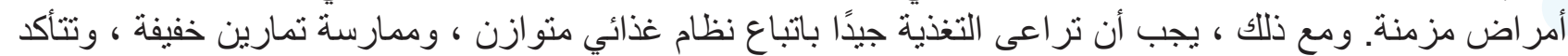
من اتباع إرشادات التباعد الاجتماعي.

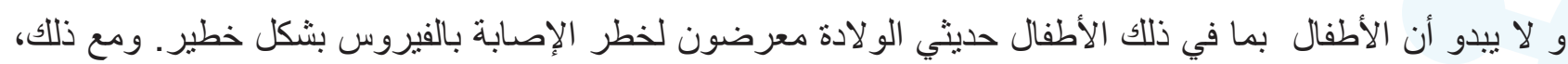

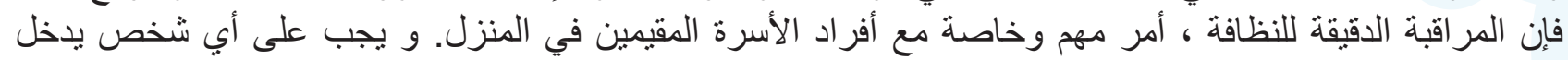

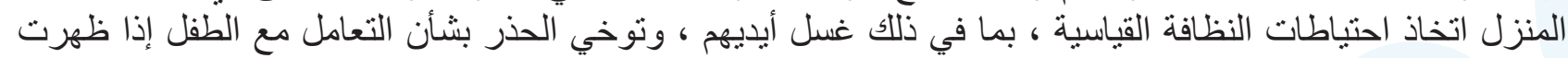

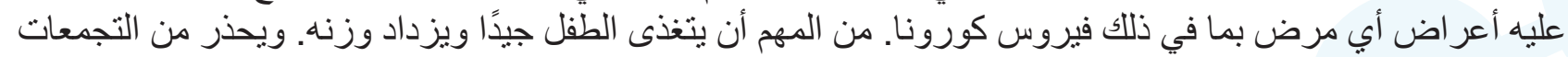

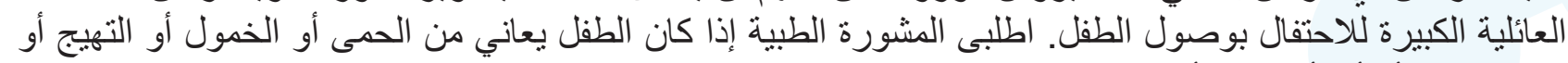
سوء التغذية أو أي أعر اض أخرى قد بكون لديكِ مخاوف منها. 


$$
\text { اتم استخلاص المعلومات السابقة من المواقع و البروتوكولات الاتية: }
$$

(Management of special conditions protocol)

r - r موقع منظمة الصحة العالمية

https://www.who.int/news-room/q-a-detail/q-a-coronaviruses

r- موقع الكلية الملكية لاطباء النساء و التوليد

https://www.rcog.org.uk/en/guidelines-research-services/guidelines/coronaviruspregnancy/covid- 19 -virus-infection-and-pregnancy/

ـ- موقع الكلية الامريكية لأطباء النساء و التوليد

https://www.acog.org/clinical-information/physician-faqs/covid-। 9-faqs-for-ob-gynsobstetrics

هـ موقع مركز مكافحة الأمر اض و الوقاية

https://www.cdc.gov/coronavirus/2019-ncov/faq.html 
تم اعداد هذه القائمة من الاسئلة والاجوبة من خلال التعاون بين قطاع السكان وتتظيم الأسرة

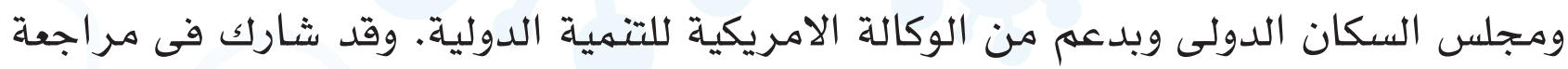

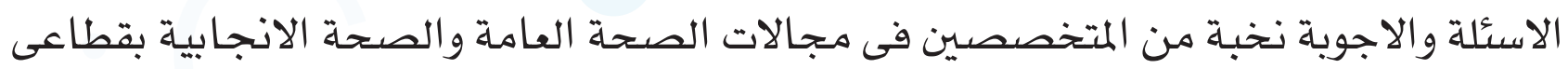

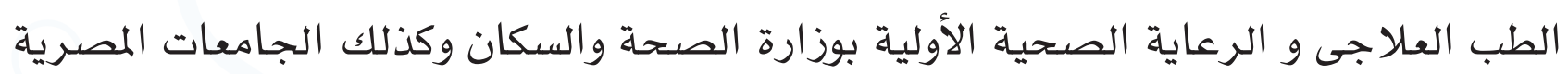

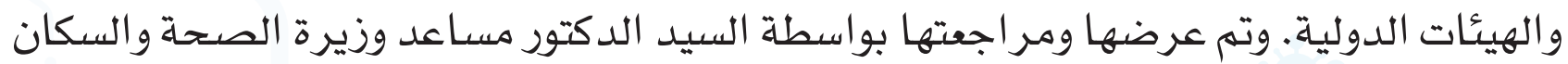
لشئون مشروعات و مبادرات الصحة العامة. 
أهمح الأسئلة و الأجوبة المتعلقة بغيروس كورونا 9 علاقته بالصحة الإنجابية وتنظيمه الأسرة 
مجلس السكان الدولى. اب. .Y. "أهم الأسئلة و الأجوبة المتعلقة بفيروس كورونا وعلاقته بالصحة

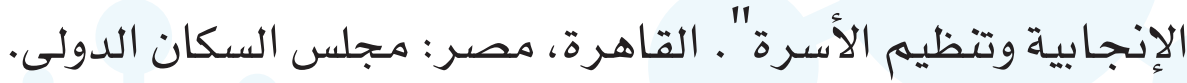

THE EVIDENCE PROJECT

مجلس السكان الدولى النى

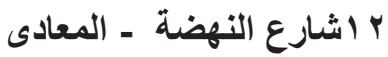

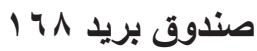

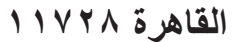

هاتف : roNkIVr

evidenceproject@popcouncil.org

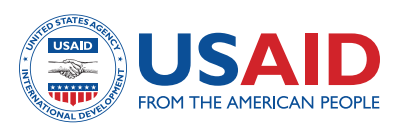

نفذ هذا المشروع بدعم من الوكالة الأمريكية للتنمية الدولية AID.OAA.A.13-00087 وفقا لأتفاقية التعاون رن الوكال (USAID) المادة ومحتويات هذا التقرير هى مسؤولية المشروع ومجلس السكان الدولى ، ولاتعكس بالضرورة أراء الوكالة الأمريكية للتنمية

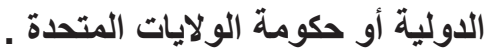

\section{Evidence}

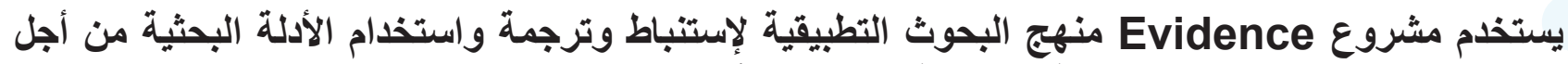

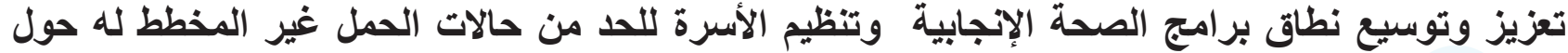

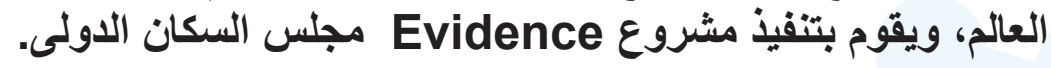


